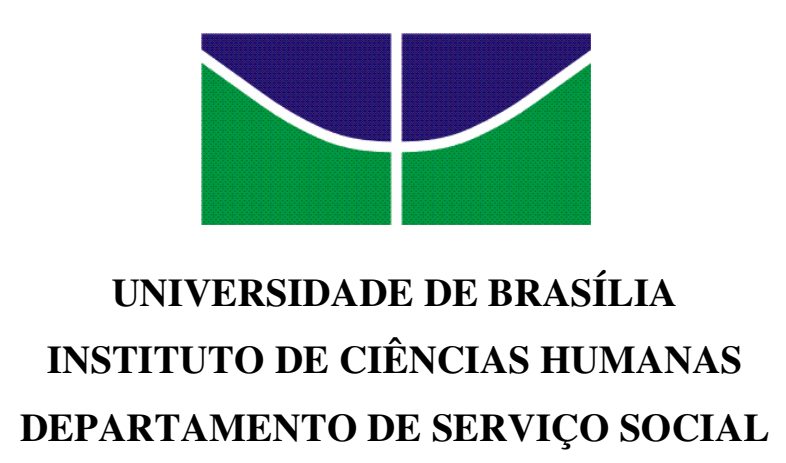

LUANA ALVES DE SOUZA

\begin{abstract}
FISCALIZAÇÃO DA EXECUÇÃO DE MEDIDAS PROTETIVAS QUANDO CUMULADAS COM MEDIDAS SOCIOEDUCATIVAS: A EXPERIÊNCIA DA VARA DA INFÂNCIA E DA JUVENTUDE DO DISTRITO FEDERAL (2006-2008).
\end{abstract}

Brasília (DF), julho de 2008. 
TRABALHO DE CONCLUSÃO DE CURSO

\section{FISCALIZAÇÃO DA EXECUÇÃO DE MEDIDAS PROTETIVAS QUANDO CUMULADAS COM MEDIDAS SOCIOEDUCATIVAS: A EXPERIÊNCIA DA VARA DA INFÂNCIA E DA JUVENTUDE DO DISTRITO FEDERAL (2006-2008).}

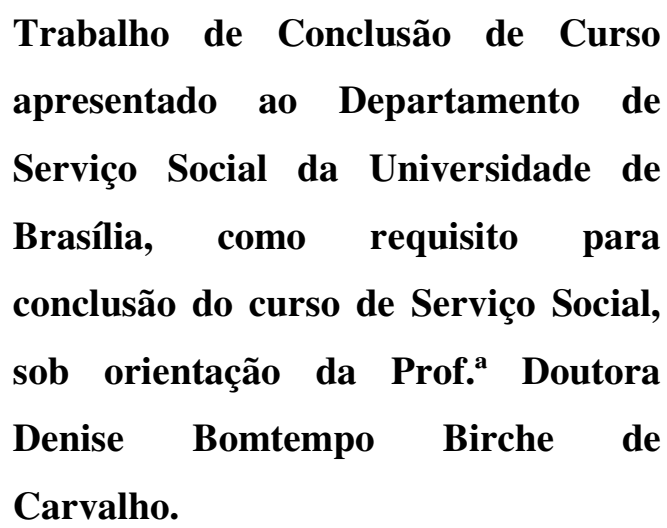

Brasília (DF), julho de 2008. 
Universidade de Brasília - UNB

Instituto de Ciências Humanas - IH

Departamento de Serviço Social

Trabalho de Conclusão de Curso - TCC

Fiscalização da Execução de Medidas Protetivas quando cumuladas com Medidas Socioeducativas: a experiência da Infância e da Juventude do Distrito Federal (2006-2008).

Aluna: Luana Alves de Souza

Orientador: Prof ${ }^{a}$. Dra. Denise Bomtempo Birche de Carvalho

Banca Examinadora:

Prof $^{\mathrm{a}}$. Dra. Denise Bonmempo Birche de Carvalho - UNB

Profe ${ }^{a}$. Mestre Patrícia Pinheiro - UNB

Assistente Social Maria Adelaide de Souza Ferreira - VIJ/DF

Brasília

Julho de 2008 
Dedico este trabalho à minha avó Paulina que, apesar de mal saber ler e escrever, me ensinou com tamanha sabedoria o seu legado: que o amor e a coragem são os ingredientes mais importantes na receita da vida. 


\section{Agradecimentos}

Por trás de toda conquista não existe apenas aquele que a conquistou. Por esse motivo, gostaria de agradecer a todas as pessoas que de alguma maneira estiveram presentes nessa minha trajetória de transformações.

À minha família, minha mãe, meu irmão e meus tios Paulo e Irene, que me apoiaram em todos os momentos, comemoram comigo cada conquista e me ajudaram nos momentos de dificuldade.

À Helô e ao Artuzinho que tornaram e tornam os meus dias ainda mais significativos, com sorrisos contagiantes e a vivacidade de seus olhares reluzentes.

Ao Igor, pelo companheirismo e paciência infindáveis e pelo seu amor, elemento fundamental em minha vida.

À minha tão querida amiga Juliana, por acreditar na minha capacidade. Sem ela, eu realmente não teria conseguido.

À "Farofa Social", por tornar os anos na UnB especiais, inesquecíveis, transformadores e, assim, marcar a história da minha vida.

Aos professores e funcionários do Departamento de Serviço Social que foram fundamentais para que esse trabalho se concretizasse.

Em especial, à denise bomtempopor terme acolhido como orientanda e aceitado o desafio de estudar sobre algo pouco falado.

À equipe da Seção de Medidas Socioeducativas, que viabilizou a realização deste trabalho e tornou as minhas tardes em um laboratório de aprendizagem fantástico.

À minha amiga Maria Adelaide, pelo carinho e atenção, bem como pela experiência de estágio, que jamais esquecerei. 
"Quando as crianças viram criminosas, as autoridades fecham os olhos. Não os delas próprias, que andam sempre bem abertos pra qualquer licitação que passe distraída. Legislam. Ah, como legislam! Obrigam todos os meios de comunicação a pôr tarja negra - ridícula - cobrindo os olhos dos "monstrinhos" que criaram, a fim de que estes não sejam identificados. E está resolvido o problema do menor" (Millô Fernandes, 1992). 


\section{RESUMO}

Esse trabalho de conclusão de curso teve por objetivo verificar como a Vara da Infância e da Juventude do Distrito Federal (VIJ/DF) fiscaliza a execução das medidas de proteção, em especial, quando cumuladas com as medidas socioeducativas. A pesquisa consistiu em um estudo de caso da VIJ/DF, fazendo uso de metodologia quantitativa e qualitativa para levantamento e análise dos dados. O trabalho de campo foi realizado a partir da análise processual e documental de vinte e quatro adolescentes atendidos pela VIJ, em específico pela Seção de Medidas Socioeducativas, e por entrevistas semiestruturadas com sete servidores da VIJ/DF, atuantes em diferentes setores da instituição e que lidam com as medidas de proteção. Os resultados encontrados evidenciam que a Vara da Infância e da Juventude (DF) lida de maneira diferenciada em relação à fiscalização das medidas protetivas aplicadas às crianças e aos adolescentes, tendo como elemento definidor da atuação a condição de vítima ou vitimizador do público atendido.

PALAVRAS-CHAVE: Medidas Protetivas, Crianças e Adolescentes, Fiscalização. 


\section{LISTA DE SIGLAS}

CAJE Centro de Atendimento Juvenil Especializado

COMPP Centro de Orientação Médico Psicopedagógico

ECA Estatuto da Criança e do Adolescente

LA Liberdade Assistida

MP Medida Protetiva

MSE $\quad$ Medida Socioeducativa

PIA Processo de Infração do Adolescente

PSC Prestação de Serviço à Comunidade

SEMSE Seção de Medidas Socioeducativas

SET Seção de Estudos Técnicos

VIJ/DF Vara da Infância e da Juventude do Distrito Federal 


\section{LISTA DE GRÁFICOS}

Gráfico $1 \quad$ Sexo dos Adolescentes Pesquisados

Gráfico 2 Idade dos Adolescentes Pesquisados à Época da Infração

Gráfico 3 Condição de Atividade e de Estudo dos Adolescentes Pesquisados

Gráfico $4 \quad$ Escolaridade dos Adolescentes Pesquisados

Gráfico 5 Composição Familiar dos Adolescentes Pesquisados

Gráfico 6 Renda Familiar Mensal dos Adolescentes Pesquisados

Gráfico $7 \quad$ Local de Moradia dos Adolescentes Pesquisados

Gráfico $8 \quad$ Tipos de Infrações cometidas pelos Adolescentes

Gráfico 9 Medidas Socioeducativas aplicadas aos Adolescentes Pesquisados

Gráfico $10 \quad$ Medidas Protetivas Aplicadas aos Adolescentes Pesquisados 


\section{LISTA DE TABELAS}

Tabela 1 Condição de atividade e de estudo por faixa etária em 2006

Tabela 2 Condição de atividade e de estudo dos adolescentes pesquisados por faixa etária em 2006

Tabela 3 Cometimento do ato infracional segundo o local de moradia dos Adolescentes Pesquisados

Tabela 4 Documentos analisados nos Processos de Infração dos Adolescentes Pesquisados 


\section{SUMÁRIO}

1. INTRODUÇÃ

$1.1 \quad$ Metodologia e Realidade da Pesquisa ..................................................... 14

1.1.1 Campo de Pesquisa: Vara da Infância e da Juventude do Distrito Federal 15

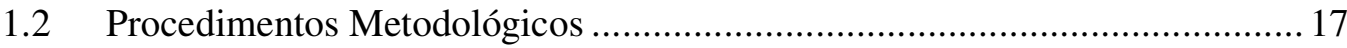

\section{CAPÍTULO I}

BREVE HISTÓRICO DOS DIREITOS DE CRIANÇAS E ADOLESCENTE NO BRASIL E AS INOVAÇÕES DO ESTATUTO DA CRIANÇA E DO

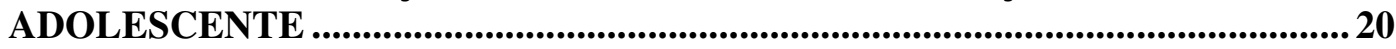

2.1 O Estatuto da Criança e do Adolescente....................................................... 24

2.1.1 Medidas Protetivas e Medidas Socioeducativas - O que são?.................26

2.1.2 A Fiscalização da Execução das Medidas Protetivas .............................. 31

\section{CAPÍTULO II}

PERFIL DOS ADOLESCENTES QUE RECEBERAM MEDIDA PROTETIVA CUMULADA COM MEDIDA SOCIOEDUCATIVA ATENDIDOS PELA

SEMSE.

\section{CAPÍTULO III}

A FISCALIZAÇÃO DA EXECUÇÃO DAS MEDIDAS PROTETIVAS CUMULADAS COM MEDIDAS SOCIOEDUCATIVAS NA VARA DA INFÂNCIA E DA JUVENTUDE DO DISTRITO FEDERAI

4.1 Fiscalização da execução das medidas protetivas: atenção dada a criança e ao adolescente na condição de vítima.

4.2 Fiscalização da execução das medidas protetivas cumuladas com medida socioeducativa: atenção ao adolescente na condição de vitimizador?

5. CONSIDERAÇÕES FINAIS ........................................................................ 65

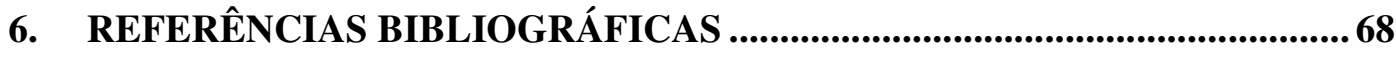

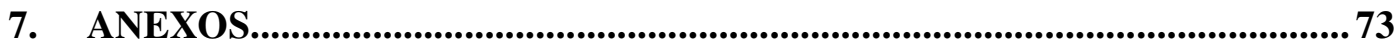




\section{INTRODUÇÃO}

A escolha pela temática deste trabalho resulta da realização de estágio na Seção de Medidas Socioeducativas da Vara da Infância e da Juventude (SEMSE/VIJ-DF). A motivação para esta pesquisa surgiu a partir do contato com os adolescentes em conflito com lei, atendidos diariamente pela SEMSE. Nesse contato foi revelada a existência de uma lacuna no acompanhamento da execução das medidas protetivas aplicadas aos adolescentes autores de atos infracionais, visto que, raramente, se observava algum questionamento por parte da Justiça a respeito da execução dessas medidas.

A partir de então, passou-se a questionar como a Vara da Infância e da Juventude do DF fiscalizava a execução das medidas de proteção aplicadas aos adolescentes em conflito com a lei, tendo em vista que tais medidas representam a garantia de direitos de crianças e adolescentes e visam a inserção desse público em políticas sociais preconizadas na Constituição de 88, tais como saúde, educação e assistência social.

Dessa forma, pensar a reinserção de adolescentes em conflito com a lei sem assegurar que estes tenham seus direitos básicos garantidos, por meio também das medidas protetivas, denota a existência de desvios na atenção dispensada a esse público, que deveria estar batizada nos preceitos da proteção integral, doutrina norteadora dos direitos de crianças e adolescentes.

Atualmente, o Brasil possui diversos mecanismos e instituições legais que reconhecem as crianças e os adolescentes como sujeitos de direito, tais como a Constituição de 1988, a Lei no 8.069 de 1990 (ECA), a Lei Orgânica da Assistência Social (LOAS), o Plano Nacional de Assistência Social (PNAS), a Lei de Diretrizes e Bases da Educação (LBD), o Conselho Nacional dos Direitos da Criança e do Adolescente (CONANDA), entre outros.

Apesar dos direitos da criança e do adolescente não estarem previstos em um único instrumento normativo, o Estatuto da Criança e do Adolescente é a Lei específica sobre tais direitos e, portanto, este será um referencial norteador deste estudo.

Três pontos fundamentais do Estatuto da Criança e do Adolescente perpassam este trabalho. O primeiro refere-se às medidas de proteção, previstas no art. 101 do Estatuto, que visam assegurar e garantir a proteção de crianças e adolescentes quando há violação ou ameaça aos seus direitos definidos em lei, seja por "ação ou omissão do Estado ou da Sociedade; por falta, omissão, ou abuso dos pais ou responsável e em 
razão de sua conduta" (ECA, 2006, p. 41). Vale destacar que a Doutrina da Proteção Integral, que foi agasalhada de forma plena pelo Estatuto, implica, sobretudo, a infância e a adolescência admitidas como prioridade imediata e absoluta exigindo uma consideração especial, por parte do poder público, sociedade e família. Ou seja, significa que a proteção de crianças e adolescentes deve sobrepor quaisquer outras medidas objetivando o resguardo de seus direitos fundamentais, assegurados pelo art. $227^{1}$ da Constituição Federal (VERONESE, 2006).

O segundo ponto refere-se ao Sistema de Garantia de Direitos da Infância e da Juventude, pensado pelo ECA enquanto o conjunto de serviços de atendimento previstos na lei, desenvolvido em três segmentos, a saber, o Sistema de Justiça (Poder Judiciário, Ministério Público e Defensoria Pública), o Sistema Administrativo de Atendimento (conselhos tutelares e conselhos de direitos) e o Sistema de Políticas Setoriais (saúde, educação, assistência social, etc.). Tal Sistema é de fundamental importância para este trabalho, visto que o controle democrático de que preconiza o Estatuto está posto na consolidação desse Sistema de Garantia.

O papel das Varas da Infância e da Juventude e dos Conselhos Tutelares enquanto operadores que atuam como reguladores - embora não exclusivos - da operação jurídica dos subsistemas de proteção especial e socioeducativos, respectivamente, responsáveis que são pela aplicação e supervisão da execução dessas medidas, atribui a esses operados um papel destacado no Sistema de Garantia de Direitos (FUNDESCOLA/MEC, 2000).

Por esse motivo, a Justiça da Infância e da Juventude é outro ponto importante para este trabalho, visto que, na visão do Estatuto da Criança e do Adolescente, esta tem um papel fundamental na solução de conflitos, que, em sua maioria, resultam da violação ou ameaça de violação dos direitos causados pelos pais ou responsáveis, pela sociedade ou pelo Estado (VERONESE, 2006, p. 132).

A fiscalização das entidades que atendem crianças e adolescentes, que subentende a fiscalização da execução das medidas protetivas, está prevista no artigo 95 do ECA, cabendo ao Poder Judiciário, Ministério Público e Conselhos Tutelares a

\footnotetext{
${ }^{1}$ O Art. 227 da Constituição da República Federativa do Brasil assegura que "é dever da família, da sociedade e do Estado assegurar à criança e ao adolescente, com absoluta prioridade, o direito à vida, à saúde, à alimentação, à educação, ao lazer, à profissionalização, à cultura, à dignidade, ao respeito, à liberdade e à convivência familiar e comunitária, além de colocá-los a salvo de toda forma de negligência, discriminação, exploração, violência, crueldade e opressão".
} 
fiscalização das entidades governamentais e não governamentais referidas no artigo $90^{2}$ do Estatuto.

Na VIJ/DF, a fiscalização das medidas de proteção dá-se por meio da comunicação da referida instituição com os órgãos executores das medidas protetivas, como por exemplo, a Secretaria de Estado de Educação do Distrito Federal, a Secretaria de Estado de Saúde do Distrito Federal, a Secretaria de Desenvolvimento Social e Trabalho do Distrito Federal, abrigos, dentre outros. A comunicação entre estas instituições ocorre via expedição de ofícios, pedido de relatórios e outros trâmites administrativos, bem como visitas às instituições que atendem as crianças e adolescentes.

A fim de apresentar um estudo da realidade, o presente trabalho teve como campo de pesquisa a Vara da Infância e da Juventude do Distrito Federal, com o objetivo de verificar como a Justiça da Infância e da Juventude fiscaliza a execução das medidas de proteção, preconizadas pelo ECA, o que permite, de certa forma, perceber como os direitos de crianças e adolescentes vêm sendo conduzidos pelo Estado (via Poder Judiciário).

A pergunta norteadora da pesquisa foi "Como a Vara da Infância e da Juventude do Distrito Federal fiscaliza a execução das medidas protetivas por ela aplicadas, quando cumuladas com medidas socioeducativas?" e teve como hipótese inicial a afirmativa de que a fiscalização da execução das medidas protetivas não se apresenta enquanto atividade consolidada na Vara da Infância e da Juventude do DF.

A metodologia utilizada será abordada em subtópico a seguir e consistiu em pesquisa bibliográfica sobre o tema, análise processual e documental de vinte e quatro adolescentes atendidos pela VIJ, em específico pela Seção de Medidas Socioeducativas, e por entrevistas semi-estruturadas com sete servidores da VIJ/DF, atuantes em diferentes setores da instituição e que lidam com as medidas de proteção.

O presente estudo está dividido em três tópicos, que se interrelacionam entre si, para explicar melhor cada temática. No primeiro capítulo faz-se uma abordagem histórica sobre os direitos de crianças e adolescentes no Brasil, evidenciando a mudança

\footnotetext{
${ }^{2} \mathrm{O}$ art. 90 do ECA determina que “ as entidades de atendimento são responsáveis pela manutenção das próprias unidades, assim como pelo planejamento e execução de programas de proteção e socioeducativos destinados a crianças e adolescentes, em regime de: I - orientação e apoio sociofamiliar; II - apoio socioeducativo em meio aberto; III - colocação familiar; IV - abrigo; V - liberdade assistida; VI semiliberdade; e VII - internação".
} 
de paradigma existente entre o ECA e o Código de Menores e ressaltando alguns obstáculos para o alcance dos objetivos propostos pelo Estatuto.

Neste mesmo capítulo, abarca-se a questão das medidas de proteção e socioeducativas, discorrendo sobre quais são e em que situações elas devem ser aplicadas, explanando sobre a importância dessas medidas para a garantia da proteção integral proposta pelo ECA. Finaliza-se o primeiro capítulo com a discussão sobre a fiscalização da execução das medidas de proteção por parte da VIJ, pontuando a relevância dessa fiscalização para o controle democrático imbricado no Sistema de Garantia de Direitos, preconizado pelo Estatuto da Criança e do Adolescente.

O segundo capítulo retrata o perfil dos adolescentes em conflito com a lei atendidos pela SEMSE e que tiveram aplicação de medida protetiva cumulada com medida socioeducativa. Objetiva-se, por meio do Perfil, tornar evidentes as condições de vulnerabilidade em que esses adolescentes se encontram, o que caracteriza o quadro de vitimizados, e não apenas de vitimizadores.

Por fim, o último capítulo apresenta os resultados obtidos com a pesquisa de campo, em que é feita a análise de como a fiscalização das medidas protetivas está posta na Vara da Infância e da Juventude do Distrito Federal, e revelando uma diferente atuação da VIJ em relação a dois públicos: os vitimados e os vitimizadores.

Encerra-se a monografia apresentando as conclusões a que essa pesquisa levou, ou seja, que apesar das dificuldades estruturais encontradas na efetivação dos direitos infanto-juvenis, principalmente no que tange a fiscalização de medidas protetivas, a VIJ/DF tem papel de destaque na garantia de direitos das crianças e dos adolescentes do DF.

\section{1 - Metodologia e Realidade da Pesquisa}

Este trabalho teve como campo de pesquisa a Vara da Infância e da Juventude do Distrito Federal, com a proposta de analisar qual o ordenamento da instituição em relação à fiscalização da execução das medidas protetivas.

Portanto, antes de apresentar a metodologia utilizada para este estudo, é importante expor a maneira como a instituição analisada está organizada, descrevendo as características específicas de cada setor da instituição no que diz respeito ao trabalho desenvolvido com as medidas de proteção. 


\subsection{1 - Campo de Pesquisa: Vara da Infância e da Juventude do Distrito}

Federal

A VIJ é uma vara especializada do Tribunal de Justiça do Distrito Federal TJDFT, e define sua missão institucional como sendo:

"Garantir os direitos da criança e do adolescente, no âmbito do Distrito Federal por meio da prestação jurisdicional, assegurandolhes condições para seu pleno desenvolvimento individual e social, possibilitando um futuro mais justo para nossa cidade e nosso país".

A estrutura da VIJ/DF é composta, basicamente, pelo Juiz Titular, Juízes Substitutos, pela Seção de Assuntos Jurídicos, pela Diretoria do Serviço de Apoio Administrativo e pela Diretoria da Secretaria do Cartório, conforme pode ser observado no organograma abaixo:

\section{Organograma da VIJ/DF}

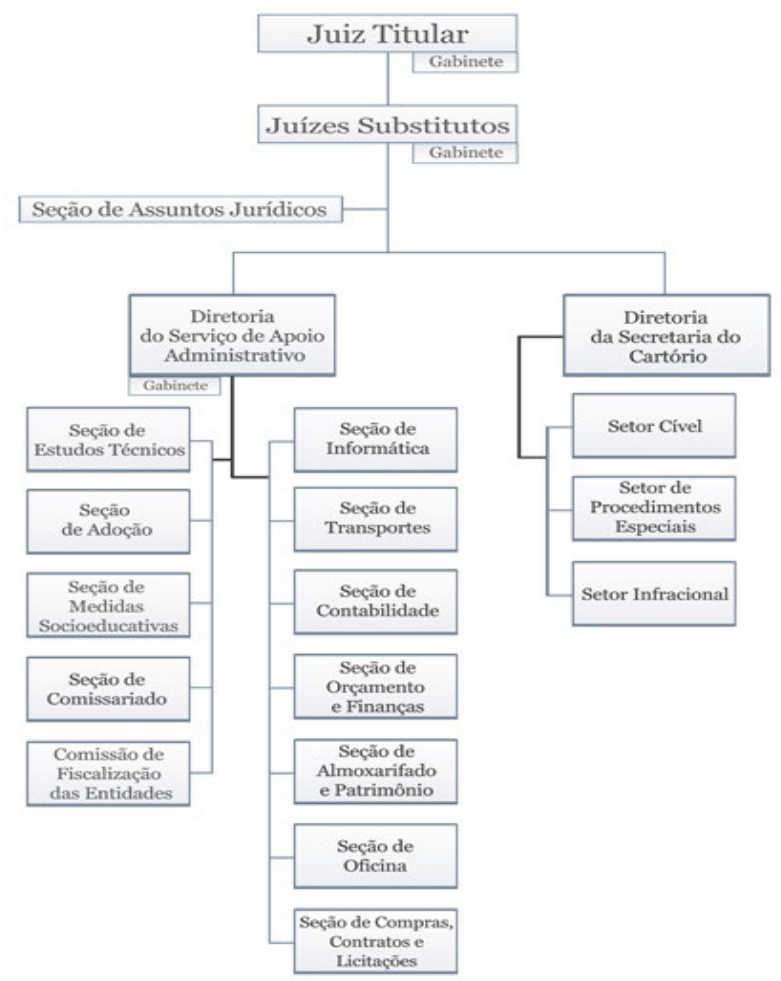

As equipes psicossociais, ou seja, compostas por psicólogos, assistentes sociais, pedagogos, dentre outros profissionais, estão inseridas na Diretoria do Serviço de Apoio 
Administrativo. A Seção de Estudos Técnicos - SET, a Seção de Adoção, a Seção de Medidas Socioeducativas - SEMSE, e a Comissão de Fiscalização das Entidades trabalham, diretamente, com a questão das medidas protetivas.

O Setor de Procedimentos Especiais do Cartório lida com a condução de procedimentos especiais, denominados Pastas Especiais, que têm por finalidade a aplicação e acompanhamento das medidas de proteção previstas no Estatuto da Criança e do Adolescente, quando se trata de crianças e adolescentes na condição de vítimas.

Já o Setor Infracional, também do Cartório, que trabalha com os Processos de Infração de Adolescentes - PIA, cuida dos processos dos adolescentes em conflito com a Lei. Nos PIA's, além da aplicação de medidas socioeducativas, pode haver, também, aplicação de medidas protetivas.

Em suma, os setores acima mencionados são os que lidam, direta ou indiretamente, com as medidas protetivas. As seções psicossociais, além de outras atribuições, são as que atendem às crianças e adolescentes. No caso da SET, são atendidos casos de violências (sexual, psicológica, física), maus-tratos, negligência, dentre outros. São feitos estudos de caso em que, na maioria das vezes, sugere-se a aplicação de medida protetiva, ou seja, a SET lida fundamentalmente com a sugestão das medidas de proteção para crianças e adolescentes na condição de vítima.

A $\mathrm{SEMSE}^{3}$, dentre outras atribuições, atende aos adolescentes que receberam medida socioeducativa, para orientá-los quanto ao cumprimento das medidas. Muitos dos adolescentes atendidos recebem também medidas protetivas ou estas são sugeridas pela própria Seção. Logo, a SEMSE fica responsável pelas medidas protetivas no caso de adolescentes em conflito com a Lei.

A Seção de Adoção, como o próprio nome sugere, trabalha com as questões relacionadas à Adoção, ou seja, trabalha diretamente na execução da medida protetiva de colocação em família substituta.

A Comissão de Fiscalização de Entidades tem como função primordial fiscalizar as entidades de abrigo do DF, para verificar se estas estão atendendo aos requisitos da Lei, ou seja, esta Comissão é a que lida com a fiscalização de medida protetiva, a priori, a medida protetiva de abrigo.

E o Cartório, seja o Setor Infracional ou o Setor de Procedimentos Especiais, trabalha com a operacionalização das decisões judiciais, oficiando as instituições,

\footnotetext{
${ }^{3}$ No próximo subtópico serão discutidas de maneira mais apropriada as atribuições da SEMSE.
} 
adolescentes e familiares, solicitando mandando de busca e apreensão, emitindo intimações pessoais, dentre outros trâmites administrativos.

\section{2 - Procedimentos Metodológicos}

Para a realização deste trabalho foi feito um estudo de caso da Vara da Infância e da Juventude com o objetivo de entender como a instituição fiscaliza a execução das medidas protetivas por ela aplicadas. Para tanto, utilizou-se técnicas quantitativas e qualitativas para levantamento e análise dos dados da pesquisa, com o intuito de consolidar os objetivos da pesquisa. Convém lembrar que foi dada atribuição de maior enfoque à pesquisa qualitativa, a partir da compreensão de que, nas ciências sociais, o aspecto qualitativo se preocupa com um nível de realidade que não pode ser quantificado.

Assim, a pesquisa qualitativa trabalha com o universo de significados, motivos, aspirações, crenças, valores e atitudes, o que corresponde a um espaço mais profundo das relações, dos processos e dos fenômenos que não podem ser reduzidos à operacionalização de variáveis (MINAYO, 2004), mostrando-se bastante condizente com o objetivo deste projeto de pesquisa.

A fim de embasar a pesquisa e dar suporte teórico ao estudo, fez-se levantamento bibliográfico a cerca da temática estudada, bem como a leitura e revisão dos textos e autores relevantes no debate concernente à promoção e defesa dos direitos da criança e do adolescente. Vale considerar que é praticamente inexistente a produção teórica sobre as medidas de proteção e a fiscalização da execução de tais medidas, com ressalva para o caso de abrigamento. Por esse motivo, as legislações brasileiras, antigas ou atuais, foram bibliografia de essencial protuberância para se travar um debate concreto baseado em normativas relevantes.

Dentro da bibliografia estudada, o arcabouço teórico a respeito da trajetória histórica dos direitos de crianças e adolescentes no Brasil, bem como o ECA e as mudanças ocasionadas com o seu surgimento, fundamentou-se na produção científica de diversos autores, tendo como principais: Vicente de Paula Faleiros (2005), Mário Volpi (1997), Irene Rizzini (1993), Josiane Veronese (2006) e Sérgio Adorno (1993).

Para embasar as questões relacionadas à fiscalização da execução das medidas protetivas, tornou-se necessário o estudo sobre a questão do controle democrático 
previsto pelo ECA e pontuações sobre a responsabilidade do Estado, com enfoque na atuação do Poder Judiciário em prestar contas de suas ações perante a sociedade e o próprio Estado. Para tanto a produção teórica de autores como Leonardo Brancher (2000) e Romualdo Santos (1999) foi tida como referencial.

Os adolescentes atendidos pela Seção de Medidas Socioeducativas foram escolhidos para traçar o perfil porque são adolescentes que estão na condição de vítima e vitimizador, e, portanto, justamente por estarem em conflito com a Lei, a maneira como a VIJ conduz os casos desses adolescentes é diferente de como os casos seriam conduzidos se os adolescentes estivessem apenas na condição de vítimas.

Como dados primários, foram utilizados os Processos de Infração dos Adolescentes (PIA's), as fichas de atendimento utilizadas pela SEMSE para realização das entrevistas com os adolescentes e as entrevistas realizadas com os funcionários da VIJ.

Para a escolha dos PIA's foi utilizada como fonte de dados secundários a Estatística de Aplicação de Medidas Protetivas Cumuladas e não-cumuladas de 2006, produzida pela SEMSE. Neste documento foi possível verificar quantos adolescentes receberam medida protetiva cumulada com medida socioeducativa (115 adolescentes). A partir de então, foi calculada a amostragem que seria pesquisada ( $21 \%$ total, ou seja, 25 processos) e, depois, foram separadas as fichas de atendimento dos adolescentes selecionados.

Em seguida, foi verificado, por meio do SISTJ, o sistema que permite verificar o andamento processual, quais processos estavam disponíveis para a pesquisa ${ }^{4}$. Por fim, foram feitas cerca de três listas com mais de 25 processos. O objetivo inicial era analisar 25 processos, entretanto, só foi possível ter acesso a 24 processos, em decorrência da tramitação deste nas diversas instâncias da VIJ, Ministério Público e Defensoria Pública.

Foi elaborado instrumental ${ }^{5}$ para a coleta de dados dos PIA's e das fichas de atendimento e as informações colhidas foram sistematizadas em um banco de dados para facilitar a manuseio com os dados e qualificar a análise.

\footnotetext{
${ }^{4}$ Os processos dos adolescentes não ficam parados no Cartório da VIJ, eles tramitam entre Ministério Público, Defensoria Pública e demais Seções da própria Vara da Infância. Dessa forma, torna-se necessário consultar o SISTJ para verificar se o processo está no Cartório para, por conseguinte, ser liberado para a pesquisa. Vale destacar que, no decorrer da pesquisa, foi necessária a elaboração de várias listas com diferentes processos, visto que, no período da elaboração das listas até a chegada delas ao Cartório, muitos processos passaram a tramitar, não estando disponíveis.

${ }^{5}$ Vide Anexo 7.1.
} 
A partir de então, foi possível traçar o Perfil dos Adolescentes, atendidos pela SEMSE no ano de 2006, que receberam medida protetiva cumulada com medida socioeducativa e verificar quais os trâmites administrativos e jurídicos foram realizados em relação à execução das medidas protetivas.

Para descrever como as medidas protetivas estão inseridas no dia-a-dia da Vara da Infância e da Juventude e como a execução de tais medidas protetivas tem sido fiscalizadas, foram realizadas entrevista semi-estruturadas com a supervisora da Seção de Estudos Técnicos, uma analista da Assessoria Jurídica, duas analistas da Seção de Medidas Socioeducativas e a supervisora da referida Seção, um analista do Cartório Infracional e a supervisora substituta da Comissão de Fiscalização das Entidades.

As entrevistas foram transcritas utilizando as técnicas do recentramento e retoque (COMBESSIE, 2004). Estas técnicas permitem sintetizar, aperfeiçoar e tornar mais claras as informações que serão encontradas de maneira difusa e dispersa nas entrevistas. Segundo Jean-Claude Combessie, esta técnica, além de facilitar o manuseio das informações para transformá-las em evidências no momento da análise dos dados, favorece o registro escrito dos temas que surgem na entrevista oral (COMBESSIE, 2004). Esse procedimento buscou esses objetivos desde que a fidelidade dos fatos, temas e evidências não fossem comprometidos.

Após a transcrição, foi realizada uma leitura na íntegra de todas as entrevistas com o objetivo de selecionar, organizar e classificar os principais fatos e temas que aparecem com mais freqüência e que podiam ser transformados em evidências. Nessa fase, a análise dos dados tornou-se possível pelo uso do processo de codificação (CRESWELL, 2007). Codificação é um processo por meio do qual é possível organizar fatos, eventos e relatos que aparecem nas entrevistas de forma dispersa e, posteriormente, transformá-los em categorias analíticas e temáticas.

Por fim, foi feita a análise comparada dos dados bibliográficos juntamente com os dados coletados com a pesquisa de campo para analisar de que maneira a Vara da Infância e da Juventude do Distrito Federal tem realizado, de acordo com o previsto no ECA, a fiscalização da execução das medidas de protetivas, em casos de cumulação com medida socioeducativa. 


\section{CAPÍtulo I}

BREVE HISTÓRICO DOS DIREITOS DE CRIANÇAS E ADOLESCENTE NO BRASIL E AS INOVAÇÕES DO ESTATUTO DA CRIANÇA E DO ADOLESCENTE

O século XX trouxe grandes transformações entorno da produção de legislação internacional que serviu de modelo para as leis internas dos Estados-nação. A grande inovação diz respeito ao direito das pessoas, que em várias instâncias, foram defendidos por instrumentos jurídicos de caráter internacional e nacional.

Em consonância com esse processo internacional, a legislação brasileira que trata dos direitos de crianças e adolescentes sofreu influência de diversas normativas e ações internacionais, visto que a discussão e o reconhecimento de crianças e adolescentes enquanto sujeitos de direito partiu de amplo e profundo debate a respeito da garantia dos direitos deste público, reconhecido o seu caráter de pessoas em desenvolvimento. Por este motivo, é importante traçar um breve histórico das legislações internacionais que embasam a legislação brasileira, para em seguida dissertar sobre o processo histórico de construção da legislação brasileira sobre o tema, marcado pela institucionalização de crianças e adolescentes.

Em 1948, na Assembléia Geral das Nações Unidas, foi adotada a Declaração Universal dos Direitos do Homem (DUDH), que corresponde ao principal documento internacional norteador e disciplinador dos direitos e liberdades fundamentais da pessoa humana e que está na base de amparo da legislação mais específica estendida à infância e juventude. O grande avanço da DUDH em relação ao público infanto-juvenil é o reconhecimento de que crianças e adolescentes "têm direito à ajuda e a assistência especiais" (BEUST, 2000).

Com dez princípios, a Declaração Universal dos Direitos da Criança (DUDC) foi proclamada em 1959, também pela Assembléia Geral das Nações Unidas. A diferença existente entre a DUDC e a DUDH é que a primeira consiste em um nível maior de detalhamento dos direitos e proteções específicos das crianças já previstos na DUDH, frisando a questão da proteção especial que deve ser garantida à criança e chamando por leis que garantam oportunidades e serviços para que as crianças possam se "desenvolver física, mental, moral, espiritual e socialmente, de forma saudável e normal, em condições de liberdade e dignidade" (BEUST, 2000, p. 62). 
Esse chamamento por leis específicas resultou no desdobramento da Convenção Internacional dos Direitos da Criança (CIDC), datada de 1989, que assumiu poder de lei interna em vários países, como o Brasil. A CIDC trouxe consigo a Doutrina da Proteção Integral $^{6}$, que visa a proteção, a defesa e a promoção integral dos direitos da população infanto- juvenil presente nas legislações atuais do Brasil.

No entanto, até a consolidação dessa doutrina no Brasil, o percurso e os debates foram imensos. Por esse motivo, a compreensão histórica dos direitos de crianças e adolescentes no Brasil é ponto fundamental para entender a importância deste trabalho, visto que, ao longo do tempo, pode-se observar uma distinção clara entre uma política para os filhos das classes dominantes e uma política para crianças e adolescentes pobres.

Para Sérgio Adorno (1993), esta história, pode ser resumida em três fases:

a primeira (1927-1973) foi marcada pela execução de normas e diretrizes repressivas e discriminatórias; a segunda (1973-1989), na qual se delineia uma política nacional caracterizada pela proteção e amparo paternalistas; a terceira, recém inaugurada (1990), fundada na concepção da criança e do adolescente como cidadãos, passíveis de proteção integral, vale dizer, de proteção quanto aos direitos de desenvolvimento físico, intelectual, afetivo, social e cultural (ADORNO, 1993, p.109).

Em se tratando da primeira fase acima descrita, pode-se dizer que neste período as crianças eram vistas como "pequenos adultos", desprovidas de direitos e reconhecidas como força de trabalho barata, desde pequenas incorporadas ao mercado de trabalho. Vale destacar que as crianças aqui referidas são aquelas pertencentes às classes, historicamente, subalternas.

O olhar sobre a infância e a juventude começa a ser modificado a partir do momento em que o Estado, ainda que de maneira ineficiente, incorpora as questões referentes a essa parcela da sociedade em suas políticas e intervenções.

A incorporação das questões recorrentes às crianças e adolescentes pelo Estado deu-se, inicialmente, por meio do Decreto $n^{\circ}$. 17.943-A, de 12 de outubro de 1927, mais conhecido como o $1^{\circ}$ Código de Menores. Tal documento representou a consolidação das leis de assistência e proteção aos menores, refletindo um profundo teor protecionista e a intenção de controle total das crianças e jovens, consagrando a aliança entre Justiça e Assistência, no que diz respeito a um novo mecanismo de intervenção sobre a

\footnotetext{
${ }^{6}$ A Doutrina da Proteção Integral consiste em assegurar para todas as crianças e adolescentes, sem exceção, o direito à sobrevivência, ao desenvolvimento e à integralidade. Importando-se também em defender as crianças das situações de risco, tanto pessoal como social.
} 
população pobre. Neste momento, constrói-se a categoria do MENOR, que simboliza a infância pobre e potencialmente perigosa, diferente do resto da infância ${ }^{7}$.

A produção teórica da época do Código de Menores compreendia o menor não apenas como o indivíduo que tinha idade inferior a 18 ou 21 anos, conforme determinava a legislação em diferentes épocas. Menor era aquele adolescente que provinha de família desestruturada, onde imperavam os maus costumes, a prostituição, a vadiagem, a debilidade moral e mais uma infinidade de características negativas, que tinha uma conduta amoral, linguagem de baixo calão, doenças, aparência descuidada, que trabalhava nas ruas e andava em bandos com companhias suspeitas (RIZZINI, 1993, p. 54).

Para aqueles que se enquadravam no conceito de menor, Vicente Faleiros (2005) explica que foram criados os orfanatos, as "rodas", as casas de "expostos", as escolas de aprendizes, a profissionalização subalterna, que resultava na inserção no mercado de trabalho pela via, principalmente, do trabalho informal.

Sérgio Adorno (1993) traz uma complementação muito interessante em relação às legislações voltadas para a infância e a Juventude. Refere que a Lei 6.697, de 10 de outubro de 1967, que instituiu o novo Código de Menores, trazia consigo uma nova doutrina - a teoria da situação irregular. De acordo com esta teoria, o ingresso de crianças e adolescentes ao mundo do direito ocorria em situação reveladora de patologia social, ou seja, situações de abandono, de carência, de vitimização e, de infração penal. Contudo, tal teoria era permeada por uma visão da ordem social bastante restrita, sendo incompatível com a desobediência civil e comportamentos "desviantes" às normas postas a todos os cidadãos, independente de suas diferenças sociais e culturais.

Logo, pautadas na teoria da situação irregular, as agências de controle da ordem pública, como é o caso do Serviço de Assistência ao Menor (SAM), da Fundação Nacional do Bem-Estar do Menor (Funabem), 1964, da Legião Brasileira de Assistência (LBA), 1946, e dos serviços de proteção à maternidade e infância da área da saúde articulados pelo Departamento Nacional da Criança (DNCr), possuíam como função primordial a repressão dos comportamentos ditos desviantes e a legislação se encarregava de proteger a ordem social contra quaisquer ataques (FALEIROS, 2005).

\footnotetext{
${ }^{7}$ Monografia, 49 páginas. Trata da violência familiar, medidas de proteção, abrigamento e reintegração familiar. Por Juliana Castilho Bittencourt. p. 8.
} 
Como já foi dito, no ano de 1989, tem-se a Declaração Universal dos Direitos das Crianças, que atribui um "novo olhar" sobre os direitos das crianças, instituindo, assim, a Doutrina da Proteção Integral:

A criança gozará de proteção especial e disporá de oportunidade e serviços, a serem estabelecidos em lei por outros meios, de modo que possa desenvolver-se física, mental, moral, espiritual e socialmente de forma saudável e normal, assim como em condições de liberdade e dignidade. Ao promulgar leis com este fim, a consideração fundamental a que se atenderá será o interesse superior da criança (Declaração Universal dos Direitos das Crianças, princípio II $^{8}$ ).

Contudo, somente em meados dos anos oitenta é que a sociedade brasileira reage contra as arcaicas diretrizes jurídicas e políticas dispensadas às crianças e adolescentes. A democratização da sociedade reclamava libertar a criança e o adolescente dessa menorização a que foram confinados desde o século XIX, situação consolidada ao longo da maior parte de vigência do regime republicano.

Nesse contexto, a Constituição Federal de 88 traz novos conceitos de proteção da criança e do adolescente, decretando os direitos infanto-juvenis sobre três grandes eixos, quais sejam, o direito à sobrevivência - vida, saúde e alimentação - o direito ao desenvolvimento pessoal e social - educação, cultura, lazer e profissionalização - e o direito à integralidade física, psicológica e moral - liberdade, respeito, dignidade, convivência familiar e comunitária. Tendo em vista que tais inovações não eram contempladas pelo Código de Menores, tornou-se necessária a formulação de uma nova lei que abrangesse toda a população infanto-juvenil. Por conseguinte, para garantir, assegurar, promover e fazer valer os direitos das crianças e adolescentes previstos na Constituição, o Código de Menores é revogado pela Lei 8.069, de 13 de julho de 1990 Estatuto da Criança e do Adolescente (ADORNO, 1993).

\section{1 - O Estatuto da Criança e do Adolescente}

Diferentemente das legislações anteriores que, em nome da "proteção dos menores", instituíram práticas violadoras de direitos e que criminalizavam a pobreza, o ECA passa a reconhecer crianças e adolescentes como sujeitos de direito e pessoas em

\footnotetext{
${ }^{8}$ Disponível em http://www.dhnet.org.br/direitos/sip/onu/c_a/lex41.htm.
} 
condição peculiar de desenvolvimento, sob a égide da Doutrina da Proteção Integral, proposta pela Convenção Internacional dos Direitos das Crianças.

A partir do Estatuto, três instâncias colegiadas de participação - Conselhos de Direito, Estado e Sociedade Civil - passaram a ser responsáveis pela promoção e garantia dos direitos desses novos sujeitos. Ao contrário do Código de Menores, a proteção às crianças e adolescentes deixa de ser uma obrigação exclusiva da família (ROCHA, E. G.; PEREIRA, J. F. 2003, p. 34).

O ECA inaugura uma nova forma de gerir os direitos da criança e do adolescente, pautada no Sistema de Garantia de Direitos, que é definido por Wanderlino Neto (1999) como um verdadeiro sistema estratégico, jurídico, político e institucional que irá se integrar e se articular na garantia do acesso de crianças e adolescentes aos serviços e programas necessários, assim como o acesso à Justiça, por exemplo.

Faleiros (2005) acrescenta que o "sistema de garantia de direitos compreende conselhos, promotorias, varas da infância, defensorias, delegacias, SOS, e núcleos de assistência e atendimento" (FALEIROS, 2005, p. 174).

O Sistema de Garantia de Direitos é dividido em três frentes, sendo a primeira responsável pela promoção de Direitos. De acordo com Margarida Garcia, esta esfera possui como objetivo específico "a deliberação e formulação de política de atendimento de direitos que prioriza e qualifica como direito o atendimento das necessidades básicas da criança e do adolescente, através das demais políticas públicas" (GARCIA, 1999, p. 96). A promoção desses direitos deve seguir a linha de pensamento da seguridade social, ou seja, deve ter como um de seus princípios a universalização dos direitos.

A segunda linha é responsável pela defesa dos direitos e tem por objetivo responsabilizar o Estado, a família e a sociedade pela falta de atendimento ou a irregularidade deste em se tratando do cumprimento dos direitos da criança e do adolescente, tendo como mecanismos de atuação as ações judiciais, os procedimentos e medidas administrativas, além da mobilização e medidas sociopolíticas (GARCIA, 1999).

O Controle Social, objetivo da terceira frente do Sistema de Garantia de Direitos, estabelece a participação de representantes da sociedade na fiscalização do cumprimento do que está previsto em Lei.

Outra inovação do ECA, e que demonstra claramente a mudança de paradigma na concepção de crianças e adolescentes enquanto sujeitos de direitos, diz respeito às medidas de proteção, ou seja, aquelas que visam garantir a proteção de crianças e 
adolescentes quando há violação ou ameaça aos seus direitos definidos em lei, seja por "ação ou omissão do Estado ou da Sociedade; por falta, omissão, ou abuso dos pais ou responsável e em razão de sua conduta" (ECA, 2006, p. 41). Assim, torna-se evidente que a adoção da Doutrina da Proteção Integral, conforme expõe Josiane Veronse, aponta como postura "irregular", não a criança, o adolescente, mas todo e qualquer agente violador, inclusive e, ousaríamos dizer que, sobretudo, o próprio poder público (VERONESE, 2006).

Entretanto, apesar da quebra de paradigma ocasionada com o ECA, que se estende desde mudanças legalistas até mudanças estruturais, como a consolidação de vários conselhos de direitos, falta uma articulação entre as três esferas de poder e demais entidades comprometidas com os direitos de crianças e adolescentes, para que os objetivos propostos pelo Estatuto sejam alcançados. Muitos dos entraves que rodam o ECA estão relacionados à situação institucional, que perpassa desde a falta de verba para executar as ações necessárias, até a falta de compromisso de profissionais que atuam na área, sem desconsiderar, também, os interesses políticos que estão em jogo.

No fundamental, o Estatuto permanece quase como letra morta para uma boa parte das crianças e adolescentes brasileiros. A persistência e o aprofundamento da crise nacional, a crise fiscal do Estado e a enorme deterioração do aparato e dos serviços públicos resultaram na precária implementação das estruturas de atendimento preconizadas pelo Estatuto (como, por exemplo, a municipalização de políticas e serviços). Mais grave ainda tem sido a falência ou o vazio de políticas e medidas que garantam o acesso universal à escola, à saúde ou aos programas de profissionalização, assim como a omissão dos poderes públicos em relação a crianças e adolescentes em situação de risco, como os chamados "meninos de rua", ou os que já enveredaram pela infração e delinqüência (CARVALHO, 2005).

Por outro lado, os princípios e determinações do Estatuto ainda não foram assimilados e aceitos por enormes setores da sociedade. Uns os consideram "irreais", "inaplicáveis"; outros, como mecanismos de proteção a "pequenos bandidos", que entravam a ação da polícia e deixam indefesos os "bons cidadãos". 


\subsection{1 - Medidas Protetivas e Medidas Socioeducativas - O que são?}

As informações apresentadas nesse capítulo são de grande validade para este trabalho, pois dentro da rotina da Vara da Infância e da Juventude do Distrito Federal, quando se aplica apenas medida protetiva, o procedimento interno é diferente de quando se aplica medida protetiva cumulada com medida socioeducativa ${ }^{9}$.

O artigo 227 da Constituição Federal assegura uma série de direitos à criança e ao adolescente, estabelecendo que estes direitos devem ser assegurados pela sociedade, pelos pais e pelo Estado.

A partir dessa premissa, o Estatuto da Criança e do Adolescente estabelece em seu artigo 98, que as medidas de proteção serão aplicadas sempre que houver violação dos direitos estabelecidos no próprio ECA por "ação ou omissão da sociedade ou do Estado", ou "por falta, omissão ou abuso dos pais ou responsável”.

Mas não somente omissões desta natureza podem motivar a aplicação das medidas de proteção. O inciso III do artigo 98 também aponta o próprio comportamento da criança ou adolescente como causa de aplicação de medidas protetivas. Segundo Marcelo Mezzono, "tais hipóteses correspondem principalmente, mas não exclusivamente, aos casos de cometimento de atos infracionais" (MEZZONO, 2005).

A nomenclatura de "medidas de proteção" é emblemática na determinação da natureza destas medidas, visto que o ECA está embasado na doutrina da proteção integral, que reconhece na criança e no adolescente indivíduos com necessidades peculiares, não perdendo de vista a condição de pessoas que se encontram em fase de desenvolvimento psíquico e físico, o que os coloca em posição de merecedores de especial atenção por parte do Estado, da sociedade e dos pais e responsáveis.

Em relação aos direitos que devem ser assegurados às crianças e adolescentes, pode-se dizer que são todos os previstos na legislação protetiva, como vida, saúde, educação, lazer, convívio familiar, etc.

Assim, as medidas protetivas que visam assegurar tais direitos estão postas no artigo 101 do ECA e são as seguintes:

\footnotetext{
I - encaminhamento aos pais ou responsável, mediante termo de responsabilidade;

II - orientação, apoio e acompanhamento temporários;

III - matrícula e freqüência obrigatórias em estabelecimento oficial de ensino fundamental;
}

\footnotetext{
${ }^{9}$ Essa diferença de procedimentos será explica de forma mais detalhada no capítulo 3.
} 
IV - inclusão em programa comunitário ou oficial de auxílio à família, à criança e ao adolescente;

V- requisição de tratamento médico, psicológico ou psiquiátrico, em regime hospitalar ou ambulatorial;

VI - inclusão em programa oficial ou comunitário de auxílio, orientação e tratamento a alcoólatras e toxicômanos;

VII - abrigo em entidade;

VIII - colocação em família substituta.

O encaminhamento aos pais ou responsável aponta duas circunstâncias que devem ser delineadas. A primeira remete-se ao fato de que tal medida é adequada às hipóteses nas quais não ocorre maior gravidade. A segunda destaca o importante papel da família, onde o adolescente deve ser mantido, muitas vezes, sendo necessário acompanhamento com programas de auxílio (FILHO E MILANO, 2004). Em suma, Mezzono exemplifica que "seria o caso de uma fuga da criança ou do adolescente, ou em casos de omissão de terceiros em relação a deveres inerentes à guarda" (MEZZONO, 2005).

A medida de orientação, apoio e acompanhamento temporários deve ser aplicada em casos onde não há uma causa que possa ser incluída dentre as hipóteses de tratamento médico-psicológico ou da aplicação das medidas dos incisos VII e VIII. Normalmente, esta medida é executada pelo Centro de Referência em Assistência Social - CRAS, ou pode ser executada pelo Conselho Tutelar, ou, ainda, pelo próprio Poder Judiciário, como afirma Mezzono.

A matrícula e freqüência obrigatórias são aplicadas quando existe evasão ou infrequência escolar. A primeira pode ser caracterizada pela completa marginalização da criança ou adolescente do sistema de ensino. A infrequência escolar está relacionada com faltas injustificadas e reiteradas à escola (MEZANNO, 2005).

Em relação à medida protetiva de inclusão em programas sociais e de auxílio, pode-se dizer que esta deve ser aplicada em situações em que a violação de direitos das crianças e adolescentes resulta de situações econômicas e financeiras que geram dificuldades. De maneira geral, esta medida é executada pelo CRAS da localidade em que a criança ou o adolescente reside.

Os incisos V e VI do artigo 101 abordam questões relacionadas à saúde, como por exemplo, dependência química, problemas psicológicos, psiquiátricos, dentre outros. Nesses casos, as crianças ou adolescentes são encaminhados aos programas de saúde que atendem à demanda. 
E, por fim, têm-se as medidas protetivas de abrigo e colocação em família substituta, visto que ambas são pautadas no vetor da excepcionalidade, ou seja, devem ser aplicadas em situações extremas e com muita cautela. Para Filho e Milano, a medida de abrigo, preservado o seu caráter excepcional, seria uma forma de passagem para a segunda, ou seja, a colocação em família substituta. Todavia, muitas crianças e adolescentes acabam em casas de abrigo por tempo superior ao devido, por falta de família, quer seja a de origem, quer seja a substituta.

É importante salientar que a aplicação destas medidas protetivas, com exceção da medida de colocação em família substituta, pode ser feita pelo Conselho Tutelar, em consonância com o artigo 136, inciso I, do ECA.

Uma questão importante para este estudo é o fato de que as medidas protetivas, conforme já mencionado, podem ser aplicadas em razão da conduta do adolescente. Dessa forma, quando o adolescente comete ato infracional e é aplicada medida socioeducativa, esta poder ser entendida como uma espécie de medida de proteção, embora seja voltada a situações relacionadas ao cometimento de ato infracional.

Tanto é que quando uma criança, ou seja, aquela com até 12 anos de idade incompletos, comete ato infracional, não pode ser aplicada medida socioeducativa, mas apenas, medida protetiva.

A aplicação de medidas, sejam elas socioeducativas (art. 112) ou protetivas (art.101), pode ser feita de forma cumulativa e combinada, não havendo um número máximo de medidas a serem aplicadas para cada caso (MEZZONO, 2005).

As medidas socioeducativas são aplicadas quando verificadas situações nas quais o comportamento do adolescente assume uma tipologia de crime ou contravenção penal, conforme previsto no artigo 103 do Estatuto.

É de se grafar que as medidas socioeducativas não têm natureza de pena, de punição. Este entendimento está pautado no $4^{\circ}$ Princípio Fundamental das Diretrizes das Nações Unidas para Prevenção da Delinqüência Juvenil, Diretrizes de Riad, que estabelece a necessidade de "medidas progressistas de prevenção da delinqüência, que evitem criminalizar e penalizar crianças e adolescentes por uma conduta, não causando grandes prejuízos ao seu desenvolvimento" (FILHO E MILANO, 2004, p. 125).

Em consonância com o artigo 112 do ECA, as medidas socioeducativas que poderão ser aplicadas aos adolescentes são:

- Advertência: admoestação verbal aplicada em casos de prática de ato infracional de pouca potencialidade lesiva; 
- Obrigação de reparar o dano: nos termos do ECA, em se tratando de ato infracional com reflexos patrimoniais, a autoridade poderá determinar, se for o caso, que o adolescente restitua a coisa, promova o ressarcimento do dano, ou, por outra forma, compense o prejuízo da vítima;

- Prestação de Serviços à Comunidade - PSC: consiste na realização de tarefas gratuitas de interesse geral, junto a entidades assistenciais, hospitais, escolas e outros estabelecimentos congêneres, bem como programas comunitários ou governamentais. A medida pode durar por até seis meses e as tarefas devem ser cumpridas durante jornada máxima de oito horas semanais. No Distrito Federal, a PSC pode ser aplicada em duas outras modalidade: Visita, em que o adolescente visita alguma instituição e produz um texto sobre (aplicada em casos de atos infracionais mais brandos, como lesão corporal, por exemplo); e a Doação, em que o adolescente (trabalhador e que não possui disponibilidade de horário para cumprir a PSC) doa um determinado valor em dinheiro à uma instituição, ambos determinados pelo Juiz.

- Liberdade Assistida - LA: medida apropriada para casos residuais, em que o adolescente tenha praticado ato infracional não tão grave e necessite de acompanhamento, auxílio e orientação. Tem como desígnios estimular o convívio familiar, estruturar a vida escolar e profissional, e propiciar elementos para inserção do adolescente na própria sociedade. $\mathrm{O}$ prazo mínimo de aplicação da LA é de seis meses;

- Semiliberdade: trata-se de medida socioeducativa que restringe a liberdade do infrator, menos rigorosa do que a internação, pois implica, necessariamente, na possibilidade de realização, por parte do adolescente, de atividades externas. São obrigatórias a escolarização e profissionalização do adolescente; e

- Internação: nos termos do ECA, a internação constitui medida privativa de liberdade, sujeita aos princípios da brevidade, excepcionalidade e respeito à condição peculiar de pessoa em desenvolvimento. Ela só poderá ser aplicada quando o ato infracional for cometido mediante grave ameaça ou violência à pessoa, por reiteração no cometimento de outras infrações graves e por descumprimento reiterado e injustificável da medida anteriormente aplicada ao adolescente. 
Destacam-se para este trabalho, as medidas socioeducativas em meio aberto, tais como a Prestação de Serviços à Comunidade e a Liberdade Assistida. Mário Volpi traz um comentário muito interessante em relação a tais medidas. Segundo o autor,

Prestar serviços à comunidade constitui uma medida com forte apelo comunitário e educativo tanto para o jovem infrator quanto para a comunidade, que por sua vez poderá responsabilizar-se pelo desenvolvimento integral desse adolescente. Para o jovem é oportunizada a experiência da vida comunitária, de valores sociais e compromisso social (VOLPI, p. 23-24).

Já a LA, considerada a medida socioeducativa mais severa em relação à PSC, é aplicada nos casos em que é verificada a necessidade de acompanhamento da vida social dos adolescentes (escola, trabalho e família). Assim,

(...) sua intervenção educativa manifesta-se no acompanhamento personalizado, garantindo-se os aspectos de: proteção, inserção comunitária, cotidiano, manutenção de vínculos familiares, freqüência à escola, e inserção no mercado de trabalho e/ou cursos profissionalizantes e formativos (VOLPI, 1997, p. 24).

Todavia, a filosofia dessas medidas socioeducativas, bem como as que restringem a liberdade dos adolescentes, encontra-se ameaçada pela inexistência ou a oferta irregular de propostas pedagógicas, o que faz com que as medidas socioeducativas resultem impostas apenas no aspecto repressivo. Adolescentes infratores, em muitos casos, são ainda tratados com maior rigor do que jovens adultos penalmente imputáveis, credores de benefícios inacessíveis aos adolescentes, como prazos reduzidos de prescrição, de substituição de penas privativas de liberdade por simples restrições de direitos, etc. (BRANCHER, 2000).

A garantia da fundamentação e a da individualização da medida, geralmente, não consta das sentenças, faltando referência à alternativa meramente protetiva. Também as sentenças e o respectivo processo restringem-se ao adolescente, sendo raras as hipóteses de aplicação simultânea de medidas aos pais ou responsáveis.

Ademais, vale frisar que todas as medidas protetivas do art. 101 podem ser aplicadas a título de medida socioeducativa, conforme prevê o inciso VII do artigo 112 do Estatuto. 


\subsection{2 - A Fiscalização da Execução das Medidas Protetivas}

Em virtude da responsabilidade do Estado enquanto responsável pela promoção de políticas sociais, as ações dele encontram-se norteadas por diversos princípios, dentre os quais se destaca o da legalidade ${ }^{10}$, que delimita o campo de atuação possível do Estado e garante aos cidadãos a titularidade de direitos. Mas esse princípio não assegura, por si só, a existência de um Estado de Justiça Social, "tornando necessário que, além da submissão aos primados da lei, haja, de fato, a participação da população para garantir seus interesses e suas necessidades" (COSTA\&LIMA, 2000, p.300).

Tal participação corresponde, além do voto, à prática do controle social, ao acompanhamento da gestão da administração pública cujos princípios estão definidos no artigo 37 da Lei Maior. Assim, verifica-se a importância do controle democrático ${ }^{11}$, que se encontra constitucionalmente previsto no parágrafo único do artigo $1^{\circ}$ da Carta Magna do Brasil.

Aliado a esse esforço de representação e participação, que é fundamental para o controle social, existe o conceito de accountability $^{12}$ no serviço público, que representa a contrapartida do Estado naquele tipo de controle.

De acordo com esse argumento, torna-se necessária a existência de órgãos integrantes da estrutura do Estado que componham uma verdadeira rede de agências de accountability, ou seja, incumbidas de supervisionar, controlar, aplicar sanções, e, sobretudo prover o cidadão das informações relativas a conduta do gestor público.

No Brasil, conforme expõe Carlos Maurício Figuerêdo (2002), esta rede de agências de accountability englobaria, dentre outros, o Ministério Público, o sistema de controle interno dos Poderes, o Poder Judiciário e os Tribunais de Contas.

Accountability, não obstante as tentativas em todos os níveis, ainda não possui um similar nacional. É um termo abrangente que vai além da prestação de contas, pura e

\footnotetext{
${ }^{10}$ Em consonância com o exposto no texto de COSTA\&LIMA (2005, p. 300), o Princípio da Legalidade, no Brasil, significa que a Administração Pública não pode fazer nada senão o que a lei determina.

${ }^{11}$ De acordo com Potyara Pereira (2002), esse controle que muitos chamam de social, será aqui denominado de controle democrático "por melhor expressar o movimento que está na base da formação desses órgãos colegiados: a regulação, pelos cidadãos, do Estado e de instituições da sociedade, com vista à ampliação da democracia”.

${ }^{12} \mathrm{O}$ termo Accountability ainda não tem tradução para o Português, mas pode ser entendido como sendo o resgate da cidadania. Não é simplesmente uma mera divulgação de informações. É fundamental a compreensão dessas informações pela sociedade e, portanto, estas devem ser dadas em linguagem clara, objetiva, sem maiores dificuldades.
} 
simples, pelos gestores da coisa pública. São mecanismos, normativos e institucionais, que se empregam nas relações entre os níveis de governo e dentro deles. Regulam, ainda, a interface entre sociedade e Estado na implantação e controle das políticas públicas. Esses instrumentos (accountability) não garantem, por si só, o bom governo ou a governança (capacidade de implantar políticas públicas) (SANTOS, 1999).

Transportando essa idéia do controle democrático em relação aos direitos de crianças e adolescentes, evidencia-se que o ECA preza pelo controle democrático através do Sistema de Garantia de Direitos, que prevê uma articulação contínua de três esferas, sendo a primeira denominada de Sistema de Justiça (Poder Judiciário, Ministério Público, Defensoria Pública) responsável pelas políticas básicas de proteção e socioeducativas, no aspecto jurisdicional.

O segundo seria o Sistema Administrativo de Atendimento, relacionado aos órgãos, serviços e programas governamentais ou não-governamentais que executem as medidas de proteção e socioeducativas. Os Conselhos de Direitos e os Conselhos Tutelares estão postos nesse sistema administrativo, responsáveis, respectivamente, pela articulação do Sistema e pela aplicação das medidas em sede não jurisdicional, e igualmente situados na esfera do Poder Executivo.

Por fim, as áreas relacionadas às políticas setoriais, embora possam ser enquadradas em sentido amplo no sistema de atendimento administrativo, não se sujeitam aqui a catalogação específica, eis que tampouco estão dispostas especificamente para atendimento exclusivo da população infanto-juvenil, preservando as respectivas denominações conforme os cortes setoriais das políticas públicas correspondentes aos sistemas de saúde, sistema de ensino, sistema de aprendizagem profissional, etc. (BRANCHER, 2000).

Embora reúna uma diversidade de ações do Estado e da sociedade civil e, assim, abranja desde instituições eminentemente formais, como o Poder Judiciário, até as mais informais, como movimentos e campanhas de solidariedade social, a prática do Sistema de Garantia de Direitos da Infância e da Juventude assenta-se em bases jurídicas relacionadas à promoção de políticas públicas.

O potencial transformador do Estatuto da Criança e do Adolescente está colocado exatamente na concepção dos direitos, institutos, órgãos e serviços que contemplam como direito subjetivo da criança e do adolescente, trazendo por conseqüência seus mecanismos coercitivos de exigibilidade e asseguramento (BRANCHER, 2000). 
Tratando-se de organização do Estado para cumprir com suas obrigações prestacionais, o Sistema de Garantia de Direitos da Infância e da Juventude responde às regras do Direito Administrativo, como base no qual se pode afirmar que

(...) a repartição das competências para a prestação de serviço público ou de utilidade pública se opera segundo critérios técnicos e jurídicos, tendo-se em vista sempre os interesses próprios de cada esfera administrativa, a natureza e extensão dos serviços, bem como a capacidade para executá-los vantajosamente para a Administração e para os administrados (BRANCHER, 2000).

Para tanto, destaca-se que a repartição das competências se opera segundo critérios técnicos e jurídicos e não segundo a vontade prevalente ditada pela autoridade de maior hierarquia ou pela lógica de conveniências do momento, embora muitas vezes por falta de clareza das competências ocorrem usurpações, excessos autoritários e abusivos, sobrepondo-se intervenções e gerando-se retrabalho e mesmo soluções incongruentes, que acabam resultando em furos na política de atenção integral destinada às crianças e adolescentes.

Para melhor compreensão do Sistema de Garantia de Direitos da Infância e da Juventude é importante situar, na relação com os programas, o papel desempenhado pelos seus principais operadores institucionais.

Sem em momento algum desprestigiar a atuação de outros importantes atores, como Conselhos de Direitos e do Ministério Público, cujos papéis de articulação e orientação técnica são, respectivamente, pressupostos da própria materialização local do Sistema de Garantias, dedicamos maior atenção, neste estudo, aos papéis mais diretamente relacionados às atividades executórias (BRANCHER, 2000).

Por isso, entendendo que os Juizados da Infância e Conselho Tutelar figuram como responsáveis pelas principais e mais intensivas interfaces do sistema, constituindo-se como elos na originação, supervisão e conclusão do processo de atendimento, têm ressaltada sua função de agentes integradores do Sistema por competência legal expressa na forma dos artigos 148 e $136^{13}$ do Estatuto, mas o mesmo não sucede com relação à integração das políticas básicas (BRANCHER, 2000).

Com o Estatuto, a negligência do Estado no cumprimento de políticas públicas básicas passou a possibilitar o recurso à via judicial. Cabe a ação havendo não-

\footnotetext{
${ }^{13}$ Art. 136: dispõe sobre as atribuições do Conselho Tutelar e o art. 148 sobre as competências da Justiça da Infância e da Juventude.
} 
oferecimento ou oferta irregular de ensino obrigatório; assistência social visando a proteção à família, à maternidade, à infância e à adolescência, bem como ao amparo às crianças e adolescentes que dele necessitem; de acesso às ações e serviços de saúde; de escolarização e profissionalização dos adolescentes privados de liberdade.

Nesse momento, é oportuno ressaltar que, conforme esclarece o Juiz de Direito da 3a Vara do Juizado Regional da Infância e da Juventude de Porto Alegre, Leoberto Narciso Brancher,

(...) dentre as medidas de proteção especial, somente se reserva à competência judicial a colocação em família substituta. Fora isso, nos casos em que não há ênfase na conflituosidade jurídica (como ocorre na aplicação pelo juiz de medidas protetivas acessórias às sócio-educativas nos termos do artigo 112, inciso VII do ECA, ou à definição da situação da criança em vias de destituição de pátrio poder e colocação em família substituta), o atendimento protetivo é da competência exclusiva - e não concorrente nem subsidiária - do Conselho Tutelar, pelo seu caráter administrativo e não jurisdicional. Tenha-se presente: as medidas sócio-educativas constituem resposta ao ato infracional, não se confundem com as medidas de proteção. No primeiro caso, o adolescente é vitimizador e, no segundo, vítima. Também que a rede administrativa não se confunde com o Sistema de Justiça. A primeira atua na assistência social, aplica medidas protetivas. A justiça age na prevenção e composição de conflitos (BRANCHER, 2000).

Com exceção da colocação em família substituta, as medidas protetivas ficam a cargo do Conselho Tutelar. Entretanto, quando aplicadas cumuladas com medidas socioeducativas, a responsabilidade pela fiscalização da execução dessas medidas fica a cargo da Justiça da Infância e da Juventude.

Assim, no dia-a-dia do atendimento realça-se o papel de operadores do Sistema de Garantia exercido pelas Varas da Infância e da Juventude e pelos Conselhos Tutelares. Pela função específica que exercem, atuam como reguladores privilegiados, embora não exclusivos da operação jurídica das medidas protetivas e socioeducativas, respectivamente, são responsáveis pela aplicação e supervisão da execução dessas medidas (BRANCHER, 2000).

Nesse sentido, podemos entender a fiscalização da execução das medidas protetivas como uma maneira de verificar se o Estado, mais especificamente, os programas e políticas públicas de proteção básica têm cumprido o seu papel na garantia dos direitos de crianças e adolescentes. 
A fiscalização da execução das medidas protetivas e socioeducativas se dá, basicamente, por meio da fiscalização das entidades de atendimento à criança e ao adolescente, prevista no artigo 95 do ECA, e estabelece que a fiscalização das entidades é dever do Poder Judiciário, Ministério Público e Conselho Tutelar.

Art. 95. As entidades governamentais e não-governamentais, referidas no Art. 90, serão fiscalizadas pelo Judiciário, pelo Ministério Público e pelos Conselhos Tutelares (ECA, 2006).

As entidades governamentais e não-governamentais mencionadas no art. 95, são responsáveis pela manutenção das próprias unidades, bem como pelo planejamento e execução de programas de proteção e sócio-educativos ${ }^{14}$ destinados a crianças e adolescentes em regime de: I - orientação e apoio sócio familiar; II - apoio sócioeducativo em meio aberto; III - colocação familiar; IV - abrigo; V - liberdade assistida; VI - semiliberdade; VII - internação (artigo 90, ECA, 2006).

Conforme expõe Charles de Abreu, entende-se que os regimes citados nos incisos de I a VI do artigo 90, "dirigem-se, mais precisamente, aos menores abandonados e carentes; já os referidos nos itens V a VII são aplicados àqueles adolescentes (jamais crianças) autores de prática de ato infracional, ou seja, a conduta descrita como crime ou contravenção penal" (ABREU, 2006, 22).

Abreu ainda ressalta que os incisos de I a IV do artigo 90 (a orientação e apoio sócio-familiar, o apoio sócio-educativo em meio aberto, a colocação familiar e o abrigo),

(...) constituem-se, portanto, verdadeiras Medidas de Proteção às crianças e aos adolescentes, sujeitos de direitos indisponíveis, que foram ameaçados ou violados por ação ou omissão do Estado ou de sociedade, por falta, omissão ou abuso dos pais ou responsável, ou ainda em razão de sua própria conduta (ABREU, 2006, p. 17).

Ao atribuir a responsabilidade de fiscalizar as entidades de atendimento destinadas a crianças e adolescentes ao poder público (Poder Judiciário e Ministério Público) e aos conselhos representativos da sociedade (Conselho Tutelar), o ECA evidencia a responsabilidade do Estado e da sociedade na garantia dos direitos de crianças e adolescentes.

14 "programas de apoio sócio-educativo de meio aberto" são os serviços que desenvolvem atividades relacionadas ao acesso às políticas básicas, em geral funcionando de forma integrada e no turno alternado da escola, que cuidam de prover acesso a cultura, esporte, lazer, profissionalização etc. 
Entretanto, os Conselhos Tutelares do Distrito Federal sofrem com o descaso por parte do Poder Público, o que reflete na falta de condições necessárias para a realização do atendimento destinado à criança e ao adolescente.

Além dessa questão, observa-se que a sociedade está mais preocupada em punir os adolescentes infratores do que em garantir seus direitos básicos, com o argumento de que eles são os responsáveis pelo aumento da criminalidade e da violência. Por esse motivo, a mídia pouco retrata a realidade precária dos conselhos tutelares e demais entidades de atendimento destinadas aos adolescentes vítimas e vitimizadores.

Por fim, o Poder Judiciário, dentro da atual conjuntura, é o que dispõe de mais recursos e, por isso, deveria não só realizar a fiscalização apresentada por este trabalho, como também instrumentalizar melhor a sociedade com informações que possam vir, em longo prazo, mostrar com autenticidade a verdadeira realidade dos adolescentes em conflito com a lei. Ou seja, a justiça deveria fiscalizar e promover campanhas para esclarecer a importância da garantia dos direitos de crianças e adolescentes, em especial, dos considerados vitimizadores. Porém, para que isso aconteça, a justiça também deve achar importante o adolescente infrator ter esses direitos garantidos. Será que ela acha? 


\section{CAPÍtULO II}

\section{PERFIL DOS ADOLESCENTES QUE RECEBERAM MEDIDA PROTETIVA CUMULADA COM MEDIDA SOCIOEDUCATIVA ATENDIDOS PELA SEMSE.}

Este capítulo tem por objetivo mostrar, a partir do perfil traçado, alguns dados sobre os adolescentes, sempre preservando o sigilo exigido pelo ECA, e também dados sobre a tramitação dos processos analisados, com enfoque na execução das medidas protetivas.

O perfil foi traçado a partir da análise de 24 processos de infração de adolescentes e das respectivas fichas de atendimento desses adolescentes, feitas pela SEMSE.

Dos 24 processos analisados, 13 estavam arquivados e os 11 restantes ainda tramitavam. Este dado é importante porque, quando um processo é arquivado significa que o adolescente já foi liberado da medida socioeducativa que lhe foi aplicada, ou seja, desde que não cometa outros atos infracionais, o adolescente não possui mais nenhuma "pendência judicial” com a VIJ. Logo, para o objetivo proposto por esta pesquisa, analisar os processos arquivados é mais interessante, porque se estaria analisando algo já acabado, finalizado.

Os demais 11 processos, apesar de estarem tramitando, não perderam a validade para este estudo porque mostram a morosidade na execução das medidas aplicadas e a atuação da VIJ no caso das medidas protetivas. E, em quatro dos onze processos, aguardava-se apenas a pronúncia do Ministério Público para o arquivamento dos autos.

Em relação ao sexo dos adolescentes pesquisados, apenas 8,3\% eram do sexo feminino.

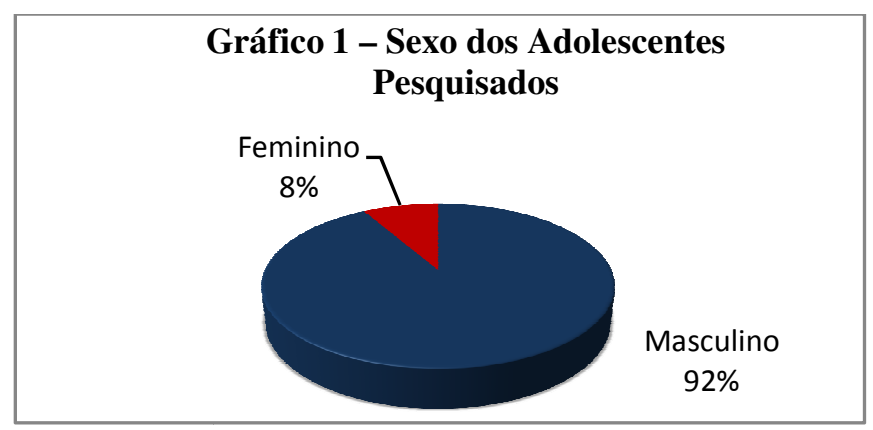


De acordo com Silva e Guerese (2003), ser jovem do sexo masculino é um fator de risco conhecido para o cometimento de infrações. Em 2002, 94\% dos adolescentes que cumpriam medida de Privação de Liberdade no Brasil, por exemplo, eram rapazes.

Um dado bastante relevante do Perfil desses adolescentes é em relação à faixa etária. O ECA determina que adolescente é aquele entre os 12 e 18 anos incompletos de idade. Neste passo, é importante fazer uma pontuação entre idade de cometimento da infração e idade de aplicação das medidas. Segundo Mezzono,

"ato infracional passível de aplicação de medida socioeducativa somente existe por pessoa entre os 12 e os 18 anos de idade. A partir dos dezoito anos, há crime ou contravenção, sujeita à disciplina penal. A aplicação da medida socioeducativa, porém, pode se estender até os vinte e um anos de idade. O processo pode, igualmente, ter início após os dezoito anos de idade do infrator. Isto ocorre porque o estatuto não tem sua aplicação condicionada pela maioridade, mas sim aos vinte e um anos de idade" (MEZZUNO, 2005, p.7).

Dentre os adolescentes pesquisados, mais de 50\% tinham entre 16 e 17 anos de idade na época em que praticaram a infração. E, dos 24 adolescentes pesquisados, 8,3\% tinham completado a maioridade quando receberam a sentença.

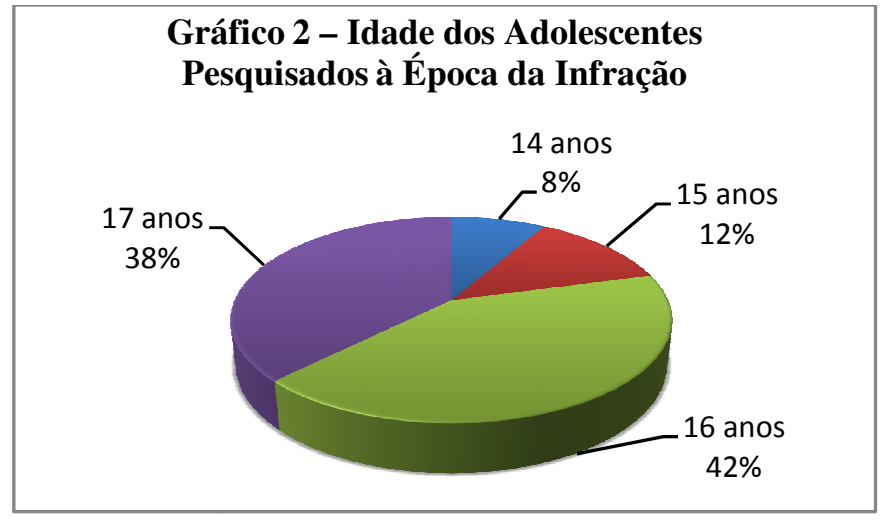

Outro dado importante em relação à faixa etária é observar a idade dos adolescentes no momento em que cometeram a infração e a idade que eles tinham quando receberam a sentença. Esta informação permite identificar qual o tempo transcorrido entre o cometimento do ato infracional e a aplicação da sentença. Por meio do banco de dados construído com as informações coletadas pelo instrumental de análise dos processos, foi possível calcular o tempo médio transcorrido entre a época do cometimento da infração até a sentença, que foi de, aproximadamente, quatro meses e dezenove dias. Esse tempo é considerado longo se pensarmos que ainda existe mais um 
período que o jovem terá que esperar para tomar ciência da sentença e ser inserido no cumprimento da medida socioeducativa.

Quanto às atividades desenvolvidas pelos jovens, convém expor que 63\% não estudavam e nem trabalhavam e que apenas $25 \%$ estudavam. Estes dados foram coletados a partir das fichas de atendimento da SEMSE, todas preenchidas em 2006.

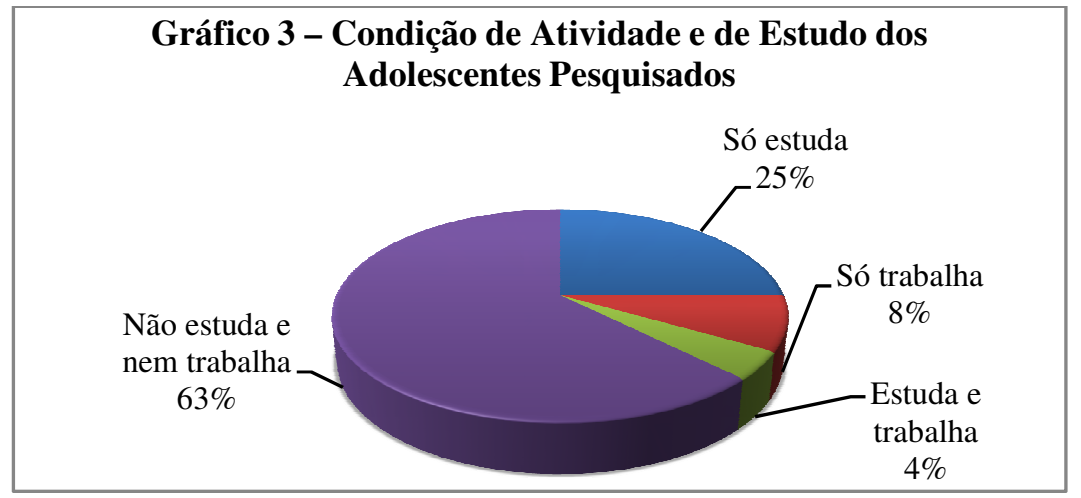

Segundo informações coletadas a partir da ficha de atendimento da SEMSE, no ano de 2006, 71\% dos adolescentes pesquisados tinham entre 15 a 17 anos de idade, e os $29 \%$ restantes tinham entre 18 a 21 anos de idade. A partir dessa informação, foi possível construir um quadro comparativo em relação a algumas informações do texto Juventude e Políticas Sociais no Brasil, produzido pelo Instituto de Pesquisa Econômica Aplicada - Ipea, no ano de 2008.

Segundo o estudo do Ipea, os dados sobre a condição de atividade e estudo dos brasileiro em 2006 assinalaram que, na faixa etária de 15 a 17 anos de idade, $60 \%$ das pessoas só estudavam, $22 \%$ estudavam e trabalhavam, $8 \%$ só trabalhavam e $10 \%$ não estudavam e nem trabalhavam.

Tabela 1 - Condição de atividade e de estudo por faixa etária em 2006

\begin{tabular}{c|c|c|c|c|c}
\hline \multirow{2}{*}{ Idade } & \multicolumn{4}{|c|}{ Situação } & \multirow{2}{*}{ Total } \\
\cline { 2 - 6 } & Só estuda & Estuda e trabalha & Só trabalha & Não estuda nem trabalha & \\
\hline 10 a 14 & $88 \%$ & $9 \%$ & $1 \%$ & $2 \%$ & $100 \%$ \\
\hline 15 a 17 & $60 \%$ & $22 \%$ & $8 \%$ & $10 \%$ & $100 \%$ \\
\hline 18 a 24 & $15 \%$ & $17 \%$ & $46 \%$ & $23 \%$ & $100 \%$ \\
\hline 25 a 29 & $3 \%$ & $10 \%$ & $66 \%$ & $21 \%$ & $100 \%$ \\
\hline
\end{tabular}

Fonte: Pesquisa Nacional por Amostra de Domicílios (Pnad\&IBGE). 
Já a condição de atividade e de estudo dos adolescentes pesquisados para este trabalho de conclusão de curso mostra que, na faixa etária de 15 a 17 anos, apenas 29\% dos adolescentes pesquisados só estudavam e 59\% não estudavam e nem trabalhavam.

Tabela 2 - Condição de atividade e de estudo dos adolescentes pesquisados por faixa etária em 2006

\begin{tabular}{c|c|c|c|c|c}
\hline \multirow{2}{*}{ Idade } & \multicolumn{3}{|c|}{ Situação } & \multirow{2}{*}{ Total } \\
\cline { 2 - 6 } & Só estuda & Estuda e trabalha & Só trabalha & Não estuda nem trabalha & \\
\hline 10 a 14 & $0 \%$ & $0 \%$ & $0 \%$ & $0 \%$ & $0 \%$ \\
\hline 15 a 17 & $29 \%$ & $6 \%$ & $6 \%$ & $59 \%$ & $100 \%$ \\
\hline 18 a 24 & $14 \%$ & $0 \%$ & $14 \%$ & $71 \%$ & $100 \%$ \\
\hline 25 a 29 & $0 \%$ & $0 \%$ & $0 \%$ & $0 \%$ & $0 \%$ \\
\hline
\end{tabular}

Fonte: dados obtidos por meio da SEMSE.

Ou seja, os dados obtidos a respeito dos adolescentes em conflito com a Lei, mostram que este grupo estava inserido de maneira inversa à média nacional sobre a condição de atividade e trabalho no ano de 2006. A respeito dessa situação, de acordo com estudo da Comissão Econômica para a América Latina e o Caribe - CEPAL (2006), baseado na tipologia desenvolvida por Figueira e Fuentes, observa-se que a educação e o trabalho são dimensões fundamentais para o desenvolvimento dos jovens como membros produtivos da sociedade. Para tanto, os autores mencionam quatro situações típicas associadas à educação e trabalho.

A primeira categoria seria a do jovem que estuda e não trabalha, caracterizado como vivendo uma situação de dependência econômica e residencial em relação aos seus pais, combinação esta mais comum entre jovens não pobres, que desempenham um papel social de "adolescentes típicos". A segunda categoria seria a dos jovens que trabalham e não estudam, e que, portanto, seriam os adolescentes com "papéis adultos". A terceira categoria seria a de jovens que estudam e trabalham e que vivenciam um momento de transição para a fase adulta.

E, por fim, a categoria que mais interessa a esta pesquisa é a dos adolescentes que não estudam e nem trabalham, visto que eles representam 59\% dos adolescentes pesquisados. Segundo o estudo da CEPAL,

(...) a última categoria compreende os jovens que não trabalham nem estudam. Os autores definem esses jovens como "isolados", uma vez que, do ponto de vista dos papéis sociais, eles perderam posições estruturais do mundo juvenil sem adquirí-las no mundo adulto (CEPAL, 2000. p.116). 
Outro dado bastante relevante para esta pesquisa é a questão da inserção dos jovens na escola, visto que uma das medidas de proteção prevista no ECA é a matrícula ${ }^{15}$ na Rede de Ensino Fundamental. Ou seja, caso o adolescente não esteja estudando, a aplicação da referida MP deveria ser uma das primeiras providências a ser tomada pelo Juízo. Na análise processual, constatou-se que somente oito adolescentes, dos vinte e quatro pesquisados, estavam estudando na época do cometimento da infração. E, dos 16 adolescentes que não estavam matriculados na rede de ensino, em cinco casos não foi aplicada a medida protetiva de matrícula.

Em relação à escolaridade dos adolescentes, observou-se que a taxa de defasagem $^{16}$ escolar foi de $87,5 \%$, ou seja, apenas três dos vinte e quatro adolescentes estavam cursando a série de acordo com a idade adequada. Além disso, a média de defasagem escolar apresentada pelos adolescentes pesquisados foi de, aproximadamente, seis anos e quatro meses, e, $87 \%$ dos adolescentes estavam cursando alguma série do Ensino Fundamental.

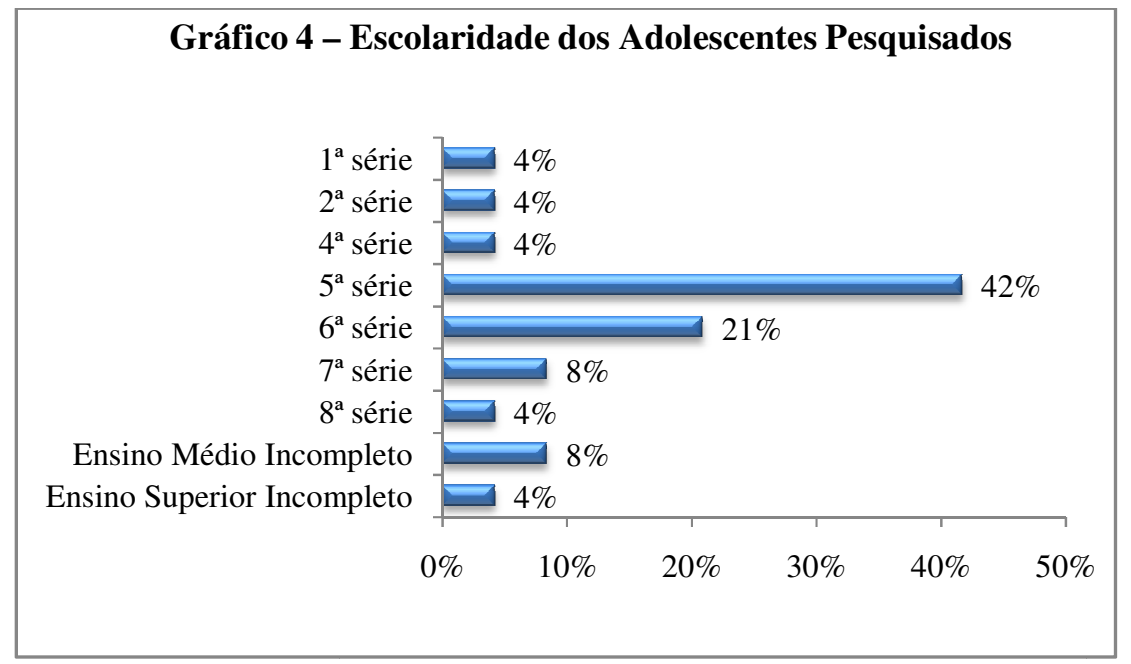

De acordo com o texto Juventude e Políticas Sociais no Brasil, publicado pelo IPEA,

(...) embora persista a identificação social do jovem como "estudante" e a escola seja amplamente reconhecida como espaço privilegiado de socialização e formação, o processo de escolarização da maioria dos jovens brasileiros é marcado por desigualdades e oportunidades

\footnotetext{
${ }_{15}$ Art. 101, inciso III do Estatuto da Criança e do Adolescente.

16 Segundo o IBGE, Taxa de defasagem idade/série - Indica a porcentagem de crianças freqüentando escola que se encontram fora das suas séries esperadas. Defasada é a criança que não frequienta a série correspondente a sua idade cronológica, ou seja, $a$ primeira série do $1^{\mathrm{o}}$ grau aos 7 anos, a $2^{\mathrm{a}}$ série aos 8 anos e daí em diante.
} 
limitadas. Predominam trajetórias escolares interrompidas pela desistência e pelo abandono, que, algumas vezes, são seguidos por retomadas. As saídas e os retornos caracterizam um percurso educacional irregular (IPEA, 2008, p. 21).

Assim, a defasagem escolar acaba se transformando na realidade de muitos. A freqüência ao ensino médio na idade adequada ainda não abrange metade dos jovens brasileiros de 15 a 17 anos, e cerca de 34\% deles ainda estão retidos no ensino fundamental. $\mathrm{O}$ acesso ao ensino superior é ainda mais restrito, com apenas $12,7 \%$ dos jovens de 18 a 24 anos freqüentando esse nível de ensino (IPEA, 2008, p. 21). A proporção de jovens fora da escola, por sua vez, é crescente conforme a faixa etária: " $17 \%$ na faixa de 15 a 17 anos, 66\% na de 18 a 24 anos, e $83 \%$ na faixa de 25 a 29 anos, sendo que muitos destes jovens desistiram de estudar sem ter completado sequer o ensino fundamental" (IPEA, 2008, p. 21).

A partir de então, torna-se evidente que existe uma relação entre adolescentes em conflito com a Lei e problemas escolares, que vão desde a defasagem até o abandono escolar. Essa relação entre escola e conflitos com a Lei é muito bem explicitada por Assis e Constantino (2005), que expõem o seguinte:

(...) problemas escolares também contribuem para a entrada no mundo infrator. Adolescentes em conflito com a lei tendem a ter poucos anos de estudo, com abandono escolar secundário dada a necessidade de trabalhar, dificuldade de conciliar escola com trabalho, desentendimento com professores e colegas, desestímulo quanto à competência escolar atestado por reprovações repetidas, baixa qualidade do ensino, pouca supervisão familiar no que se refere à freqüência escolar do jovem (ASSIS\&CONSTANTINO, 2005, p. 3).

A composição familiar dos adolescentes evidencia que a maioria reside em companhia de algum familiar. A figura da mãe está presente em $84 \%$ dos casos e a do pai em, apenas, $21 \%$. 


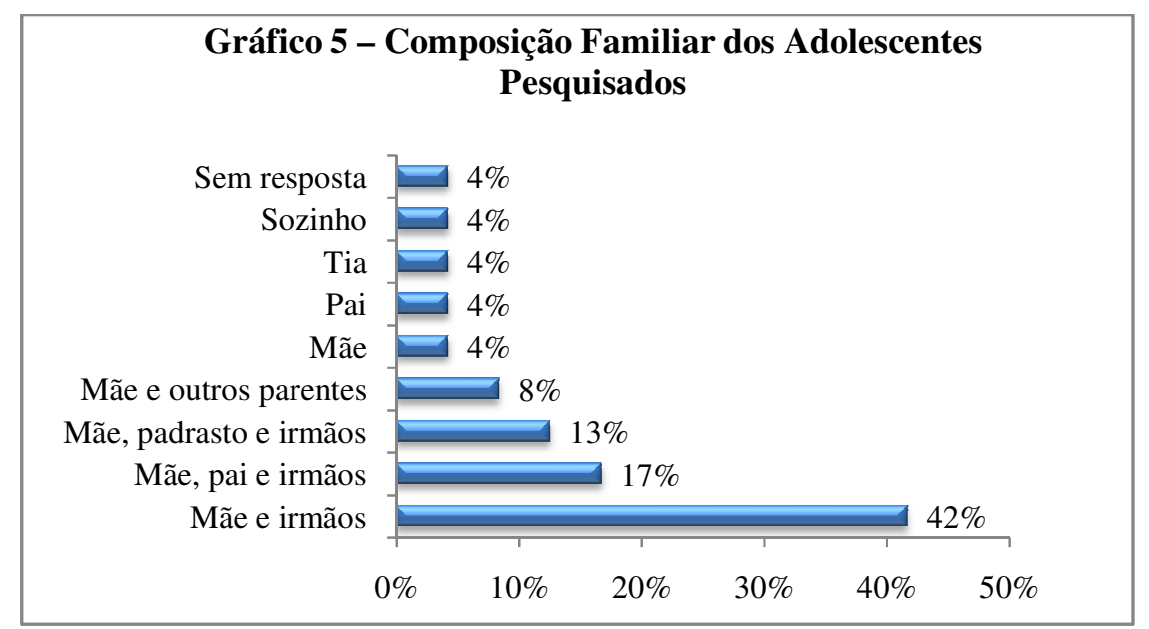

A situação familiar pode representar um fator de risco no caso de adolescentes

em conflito com a Lei, conforme Assis e Constantino (2005) descrevem:

As famílias de jovens envolvidos em infrações tendem a ser mostradas como potenciais fatores de risco, revelando extremo grau de fragilidade, por várias situações: precária situação socioeconômica; deficiente supervisão por separação dos pais; ausência da mãe do lar devido ao trabalho ou distanciamento da figura paterna; mortes e doenças rotineiras na família; relacionamentos marcados por agressões físicas e emocionais, precário diálogo intrafamiliar e dificuldades em impor disciplina (ASSIS\&CONSTANTINO, 2005, p. 83).

Além do mais, em $48 \%$ dos casos as famílias eram chefiadas apenas pela figura materna, sem falar que, em $42 \%$ dos casos a família dos adolescentes pesquisados era composta pela genitora e irmãos. Nesse sentido, Alex Gallo e Lúcia Williams mostram que

A mulher, na maioria das vezes chefiando tais famílias, lida com o estresse de prover financeiramente a casa, assim como educar os filhos. Não é o simples fato de viver em famílias monoparentais que implica problemas no desenvolvimento infantil, mas a relação que essa condição tem com outras variáveis de risco (...) mães que lidam com um nível de estresse maior para prover financeiramente a casa e cuidar dos filhos, sem o apoio do parceiro. Essa dificuldade, aliada a uma rede de apoio ineficaz (ausência de apoio do parceiro, falta de recursos na comunidade como creches, entre outros), pode afetar diretamente o estilo parental que é estabelecido (GALLO\&WILLIMAS, 2008, p. 50). 
A renda familiar mensal é um dado bastante importante para entender em que nível socioeconômico o adolescente está inserido. A renda familiar variou entre zero a $\mathrm{R} \$ 1.200,00$, sendo que a média foi igual a $\mathrm{R} \$ 378,00$. O salário mínimo no ano de 2006 correspondia a 350,00 reais $^{17}$. A partir dessa informação, constatou-se que $80 \%$ das famílias em que os adolescentes estavam inseridos sobreviviam com um valor de um a três salários mínimos, o que confirma o baixo poder aquisitivo dos adolescentes pesquisados.

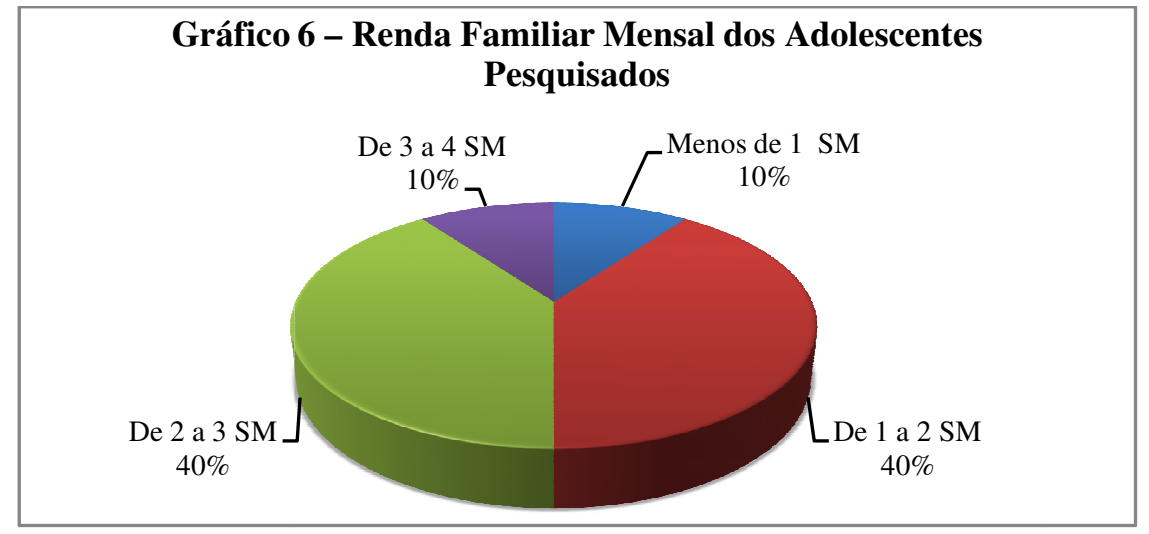

Assim, pode-se dizer que a pobreza acaba se tornando um fator de risco para adolescentes, entretanto, ser adolescente pobre não é sinônimo de ser adolescente em conflito com a Lei, conforme assinalam Gallo e Williams,

A pobreza acarreta problemas graves para o desenvolvimento humano, embora ela, per se, não seja um fator de risco para a conduta infracional, haja vista o grande contingente de jovens pobres que não se envolve em atos infracionais. Entretanto, argumenta-se que o estresse provocado pelo baixo poder aquisitivo é considerado um fator de risco que dificulta as relações entre pais e filhos, levando a um estilo parental pouco efetivo. A condição social em que as famílias de baixo poder aquisitivo se encontra pode acarretar baixo monitoramento das atividades dos filhos, baixo nível de afeto, indiferença generalizada e vínculo pouco afetivo nas relações interpessoais, o que caracterizaria um estilo parental negligente, podendo favorecer comportamentos anti-sociais dos filhos (GALLO\&WILLIAMS, 2008, p. 48).

Quanto ao uso de drogas, apenas cinco adolescentes não usavam drogas. Dos 19 restantes e usuários de drogas, verificou-se que todos eram usuários de maconha. Desses adolescentes, cinco usavam, ainda, mais outro tipo de droga: dois usavam maconha, thiner e cola; um usava maconha e cocaína; e outro usava maconha e rupinol. O uso de

\footnotetext{
${ }^{17}$ Segundo a Lei n ${ }^{\circ}$ 11.321, de 07 de julho de 2006, publicada no Diário Oficial da União de 10.07.2006.
} 
drogas representa um fator de risco importante, e está muito associado aos grupos em que os adolescentes estão inseridos, conforme expõe Assis e Constantino (2005)

O uso de drogas é outro fator de risco importante, geralmente associado à convivência no grupo de pares. Muitos programas abordam as duas questões conjuntamente. É expressiva a quantidade de usuários de drogas entre os adolescentes privados de liberdade no País: em 2002, 85,6\% faziam uso antes da apreensão, especialmente, de maconha $(67,1 \%)$, álcool $(32,4 \%)$, cocaína/crack $(31,3 \%)$ e inalantes $(22,6 \%)$. Adolescentes infratores tendem a procurar amigos no próprio meio de infração, buscando estímulo e apoio em suas ações ilegais como roubos, tráfico ou uso de drogas (ASSIS e CONSTANTINO, 2005, p.84).

O local de moradia dos adolescentes pode ser representado pelo gráfico abaixo.

Cerca de 30\% dos adolescentes residem na cidade satélite de Ceilândia, seguida pela cidade de Planaltina, com 16,7\% dos adolescentes. Vale destacar que um dos adolescentes reside em uma cidade do Goiás, Céu Azul, localizada no entorno do Distrito Federal.

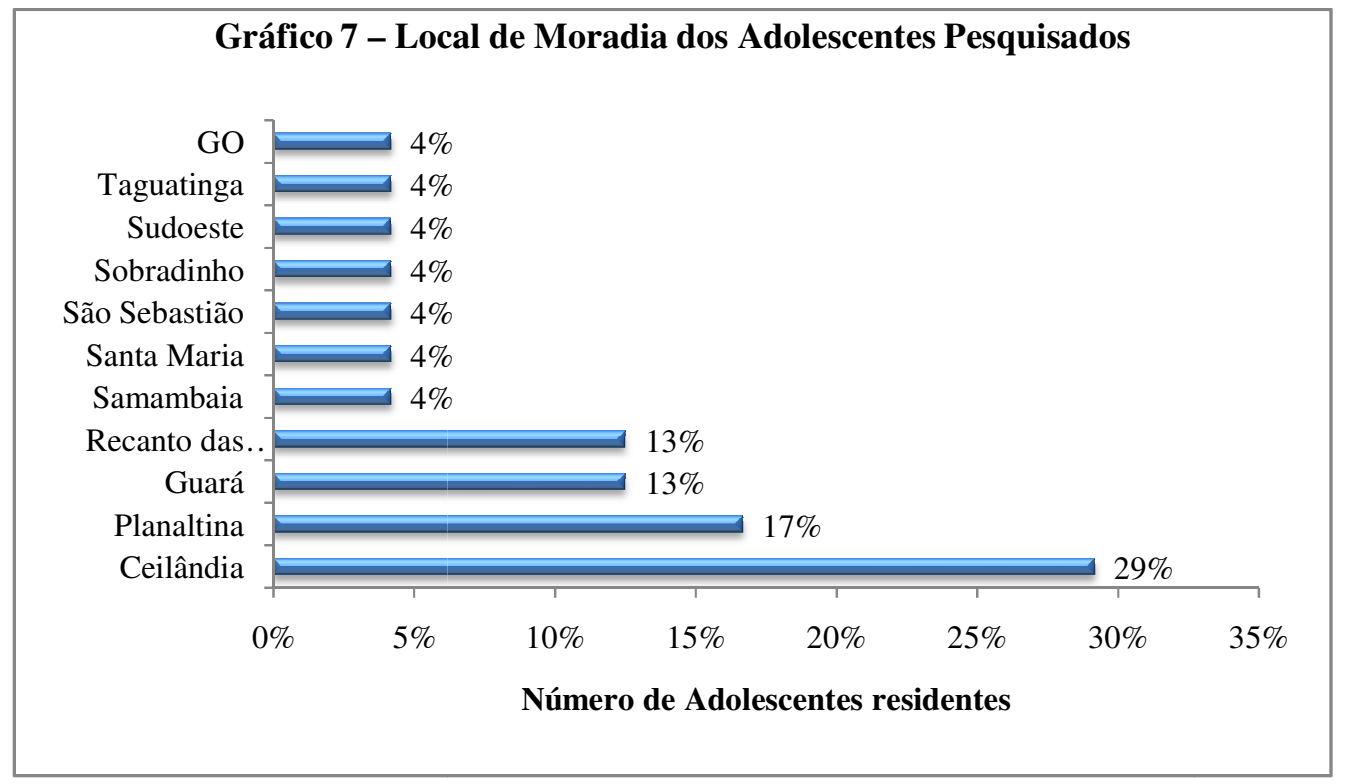

O local de cometimento do ato infracional nem sempre é o mesmo do local onde o adolescente reside, conforme evidencia a tabela 3. Por meio da análise dos dados, constatou-se que a maioria dos adolescentes cometeu os atos infracionais no mesmo local em que residem. E, entre os locais em que houve cometimento de ato infracional e que não era o mesmo local de residência dos adolescentes destaca-se o Plano Piloto, 
seguido, respectivamente, por Taguatinga, Ceilândia, Planaltina e São Sebastião. Os atos infracionais cometidos no Plano Piloto foram: dois portes e uso de drogas, tentativa de furto e porte de arma, o que mostra que a cidade pode ser alvo de atos infracionais tendo em vista o maior poder aquisitivo dos moradores.

Tabela 3 - Cometimento do ato infracional segundo o local de moradia dos Adolescentes Pesquisados

\begin{tabular}{|c|c|c|c|c|c|c|c|c|c|c|c|}
\hline \multirow[b]{2}{*}{ Local de Moradia } & \multicolumn{10}{|c|}{ Local da Infração } & \multirow{2}{*}{$\begin{array}{l}\text { Total } \\
\text { geral }\end{array}$} \\
\hline & Ceilandia & Guará & Planaltina & $\begin{array}{l}\text { Plano } \\
\text { Piloto }\end{array}$ & $\begin{array}{c}\text { Recanto } \\
\text { das Emas }\end{array}$ & Samambaia & $\begin{array}{l}\text { Santa } \\
\text { Maria }\end{array}$ & $\begin{array}{c}\text { São } \\
\text { Sebastião }\end{array}$ & Sobradinho & Taguatinga & \\
\hline Ceilândia & 4 & 0 & 1 & 0 & 0 & 0 & 0 & 1 & 0 & 1 & 7 \\
\hline Céu Azul - GO & 0 & 0 & 0 & 1 & 0 & 0 & 0 & 0 & 0 & 0 & 1 \\
\hline Guará & 1 & 1 & 0 & 0 & 0 & 0 & 0 & 0 & 0 & 1 & 3 \\
\hline Planaltina & 0 & 0 & 3 & 1 & 0 & 0 & 0 & 0 & 0 & 0 & 4 \\
\hline Recanto das Emas & 0 & 0 & 0 & 0 & 3 & 0 & 0 & 0 & 0 & 0 & 3 \\
\hline Samambaia & 0 & 0 & 0 & 0 & 0 & 1 & 0 & 0 & 0 & 0 & 1 \\
\hline Santa Maria & 0 & 0 & 0 & 0 & 0 & 0 & 1 & 0 & 0 & 0 & 1 \\
\hline São Sebastião & 0 & 0 & 0 & 0 & 0 & 0 & 0 & 1 & 0 & 0 & 1 \\
\hline Sobradinho & 0 & 0 & 0 & 0 & 0 & 0 & 0 & 0 & 1 & 0 & 1 \\
\hline Sudoeste & 0 & 0 & 0 & 1 & 0 & 0 & 0 & 0 & 0 & 0 & 1 \\
\hline Taguatinga & 0 & 0 & 0 & 1 & 0 & 0 & 0 & 0 & 0 & 0 & 1 \\
\hline Total geral & 5 & 1 & 4 & 4 & 3 & 1 & 1 & 2 & 1 & 2 & 24 \\
\hline
\end{tabular}

Segundo informações da Secretaria de Estado de Segurança Pública do Distrito Federal $^{18}$, Ceilândia e Planaltina são consideradas as cidades satélites mais violentas do DF, seguidas por Santa Maria, Recanto das Emas e Brazlândia. Apesar dos dados serem de 2008, pode-se observar que dos adolescentes atendidos pela SEMSE em 2006, a maioria residia na Ceilândia e a maior parte dos atos infracionais foi cometida nas cidades de Ceilândia, Planaltina e Recanto das Emas.

O gráfico 8 apresenta as infrações mais cometidas pelos adolescentes pesquisados que foram, respectivamente, roubo, porte e uso de drogas, furto e porte de arma, que, juntas, representam mais de $80 \%$ do total. A propósito, não foi registrado nenhum ato infracional de tentativa de homicídio ou homicídio, e as infrações mais cometidas são de baixo potencial ofensivo.

\footnotetext{
${ }^{18}$ Disponível em: http://www.ssp.df.gov.br/.
} 


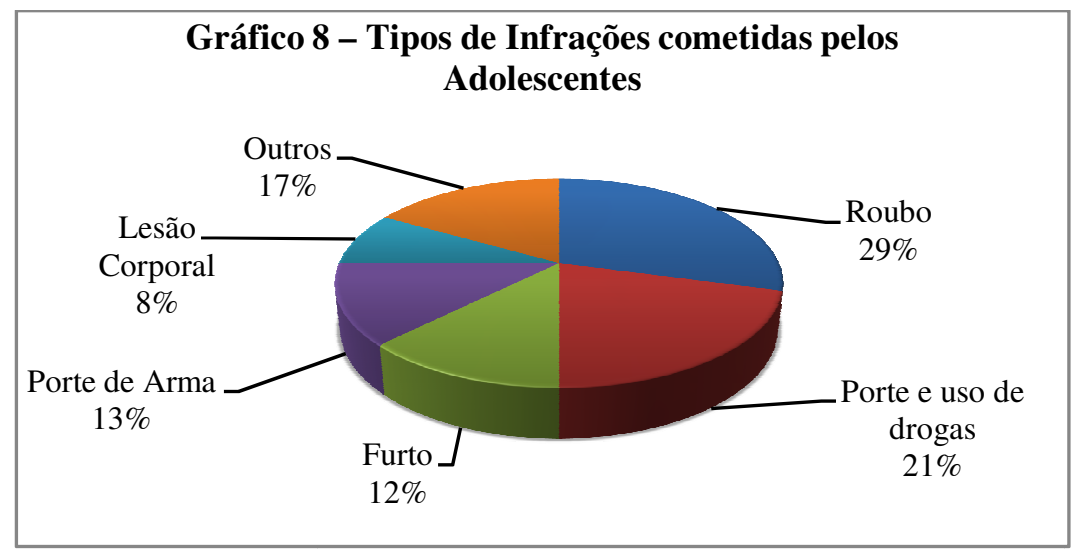

Esse dado é importante porque se discute muito, na atualidade, a respeito da diminuição da maioridade penal, e um dos principais argumentos gira em torno da fala de que adolescentes que cometem atos infracionais compatíveis com crimes hediondos, como homicídio, por exemplo, devem ser julgados pelo sistema de justiça comum. E, além disso, é atribuído a estes jovens a responsabilidade pelo aumento da criminalidade no Brasil. Entretanto, além dos adolescentes serem responsáveis por um percentual baixo se comparado ao total de crimes praticados no país, a maior parte das infrações cometidas por eles são infrações contra o patrimônio, ou seja, não são infrações praticadas sob grave ameaça ou violência à pessoa. A respeito desse ponto, Andréia Segalin e Clarete Trzcinski (2006), mostram que

Dados publicados pelo Ministério da Justiça (2005) revelam que, dos crimes praticados no país, somente $10 \%$ são atribuídos a adolescentes, sendo que, deste percentual, $78 \%$ são infrações cometidas contra o patrimônio, $50 \%$ são furtos e $8 \%$ atentam contra a vida. Em síntese, segundo informação da Associação Brasileira de Magistrados e Promotores da Infância e Juventude, menos de $3 \%$ dos crimes violentos são praticados por adolescentes (SEGALIN\&TRZCINSKI, 2006, p. 1).

Além disso, é importante salientar que a avaliação da sociedade sobre a ocorrência do ato infracional se faz numa perspectiva de polícia e segurança pública, referenciando, sobremaneira, nos meios de comunicação, às conseqüências do ato. Assinalam Abramo, Freitas e Sposito (2000, p. 8) que o senso comum da visão societária dominante culpabiliza os jovens como "principais causadores da violência [...] irremediavelmente individualistas, apáticos, consumidores vorazes de produtos ou mercadorias inúteis e desinteressados das questões públicas”. 
Como já foi dito anteriormente, foram analisados processos de adolescentes que receberam medida socioeducativa cumulada com medida protetiva. Dentre as medidas socioeducativas mais aplicadas, estão a Liberdade Assistida, com 65\% de aplicação, a Prestação de Serviços a Comunidade, com 18\%, e a Liberdade Assistida cumulada com a Prestação de Serviço à Comunidade, com 13\% de aplicação. Ambas são medidas socioeducativas em meio aberto, ou seja, os adolescentes que recebem essas medidas não são privados de liberdade.

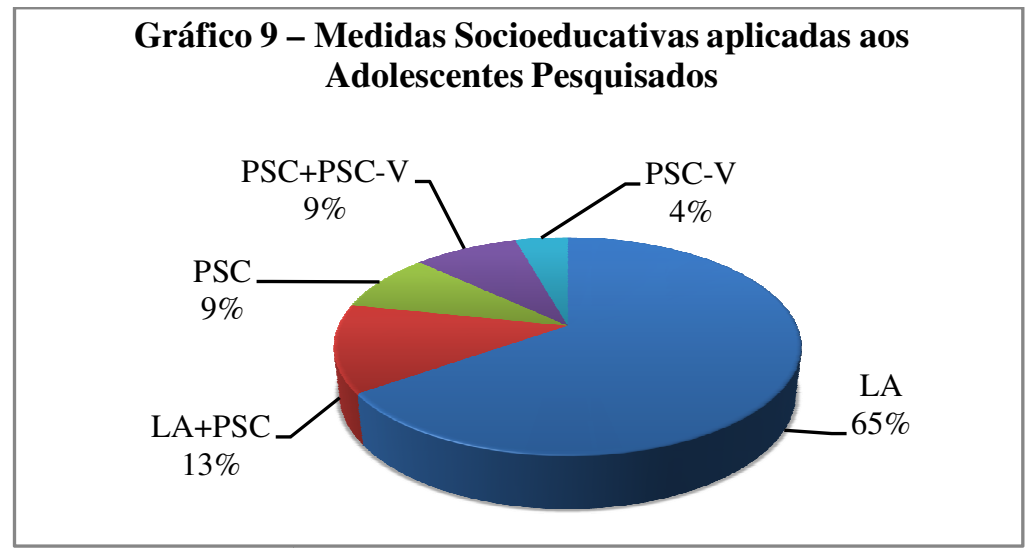

A liberdade assistida é a medida socioeducativa considerada mais "severa" dentre as medidas socioeducativas em meio aberto, tendo como objetivo a reconstrução dos vínculos sociais, familiares e comunitários dos adolescentes. A respeito disso, Leila Brito (2007) diz que

(...) a liberdade assistida, nos parâmetros da doutrina de proteção integral, deve estar voltada para os saudáveis vínculos a serem mantidos ou estabelecidos entre o adolescente e seu grupo doméstico e comunitário. Acredita-se que essa medida reconstrói no adolescente a sua atividade, os seus valores, a sua convivência familiar, social, escolar e profissional (BRITO 2007, p. 135).

Já a Prestação de Serviços a Comunidade, considerada uma medida socioeducativa menos severa, tem como pressuposto fundamental a inserção do adolescente em conflito com a Lei em atividades não remuneradas. Gallo e Williams, afirmam que

A Prestação de Serviços à Comunidade, apesar de ser uma medida menos severa, parece ser útil, pois envolve o desenvolvimento de atividades, que podem, por sua vez, adaptar o adolescente ao convívio social e profissional. Ou seja, o adolescente em cumprimento de tal 
medida, com o devido acompanhamento, passa a se relacionar com outras pessoas, aprende um ofício e acaba desenvolvendo um repertório social. (GALLO\&WILLIAMS, 2008, p. 55).

Sobre as medidas de proteção ${ }^{19}$, em $41,7 \%$ dos casos foram aplicadas mais de uma medida protetiva. Por meio do gráfico 6, pode-se perceber que as medidas protetivas mais aplicadas foram as dos incisos III e VI, que estiveram presentes em 50\% dos casos, cada uma. Em segundo lugar, tem-se a media protetiva do inciso V, que aparece em 29,2\% dos casos. E, em terceiro lugar, com 20,8\% de freqüência nos casos analisados, destaca-se a MP do inciso IV.

Um paralelo interessante que pode ser traçado em relação à MP do art. 101, inciso VI, referente a tratamento para toxicômanos e alcoólatras, é que dos 19 adolescentes que declararam ser usuários de drogas, apenas 57,9\% receberam a medida protetiva em questão.

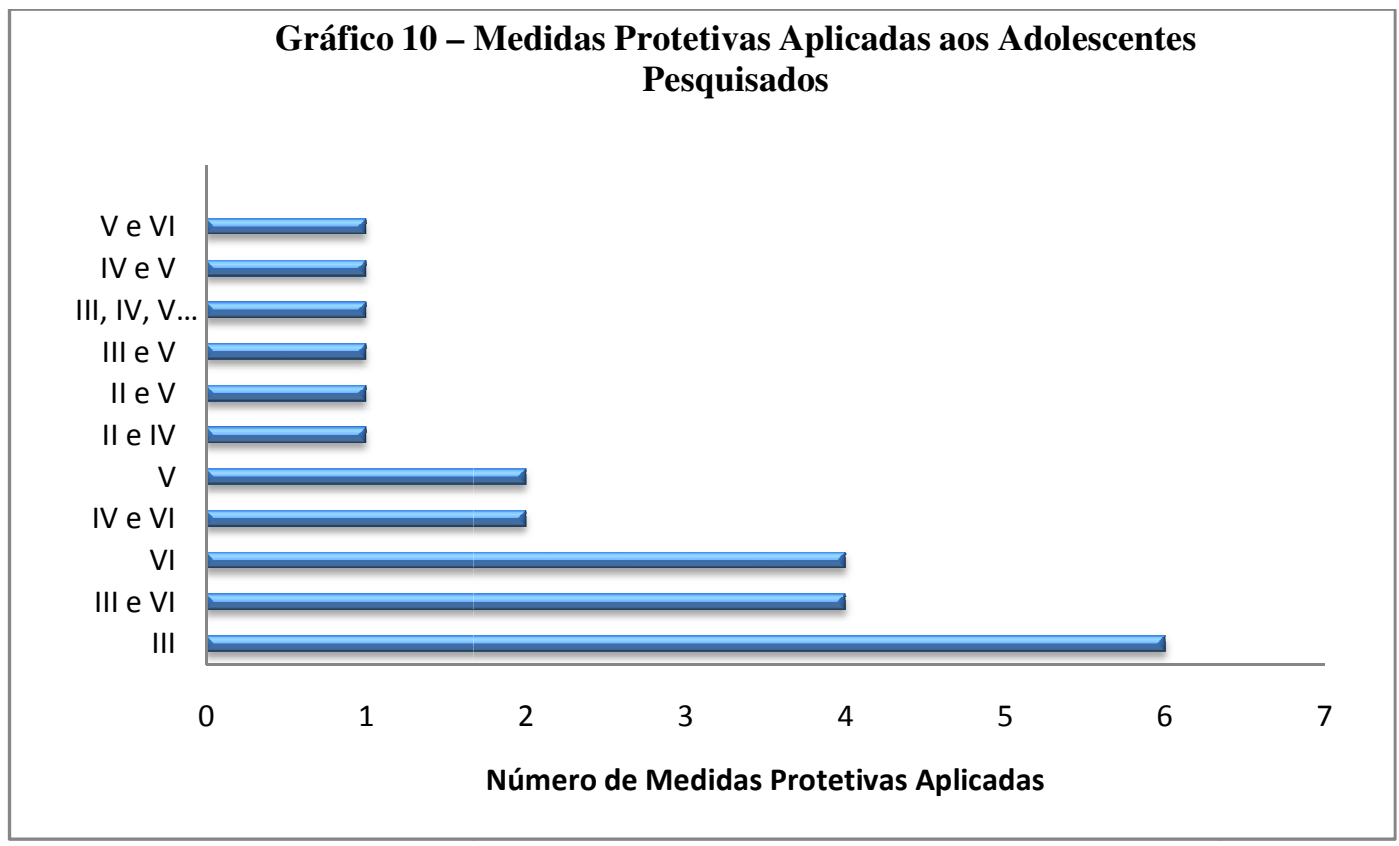

Por fim, os dados obtidos com este perfil revelam, claramente, que os adolescentes em conflito com a Lei, embora o olhar da Justiça focalize, essencialmente,

\footnotetext{
${ }^{19}$ Medidas de proteção são as previstas no artigo 101, incisos de I à VIII do Estatuto da Criança e do Adolescente. São elas: I - encaminhamento aos pais e responsável, mediante termo de responsabilidade; II - orientação, apoio e acompanhamento temporários; III - matrícula e frequiência obrigatórias em estabelecimento oficial de ensino fundamental; IV - inclusão em programa comunitário ou oficial de auxílio à família, à criança e ao adolescente; V - requisição de tratamento médico, psicológico ou psiquiátrico, em regime hospitalar ou ambulatorial; VI - inclusão em programa oficial ou comunitário de auxílio, orientação e tratamento a alcoólatras e toxicômanos; VII - abrigo em entidade; e VIII - colocação em família substituta.
} 
suas condições de vitimizadores, são tão vítimas da violência posta pela sociedade e pelo Estado quanto as crianças e adolescentes considerados apenas vítimas, visto que "situações de negligências e abandono, pobreza, criminalidade e violência na família, escola, comunidade e sociedade em geral são usuais entre adolescentes em conflito com a lei" (ASSIS e CONSTANTINO, 2005, p.83).

Como já foi dito, a violência, tendo os jovens como vítimas ou vitimizadores, está densamente conectada com a condição de vulnerabilidade social destes indivíduos. Atualmente, esses atores sofrem um risco de exclusão social sem precedentes devido a um conjunto de desequilíbrios provenientes do mercado, Estado e sociedade que tendem a concentrar a pobreza entre os membros desse grupo e distanciá-los do "curso central" do sistema social. (UNESCO, 2002).

Outro aspecto perverso da vulnerabilidade é a escassa disponibilidade de recursos materiais ou simbólicos a indivíduos ou grupos excluídos da sociedade. O nãoacesso a determinados insumos (educação, trabalho, saúde, lazer e cultura) diminui as chances de aquisição e aperfeiçoamento desses recursos que são fundamentais para que os jovens aproveitem as oportunidades oferecidas pelo Estado, mercado e sociedade para ascender socialmente.

A fiscalização das entidades executoras de medidas protetivas e socioeducativas é competência do Poder Judiciário, Ministério Público e Conselhos Tutelares, conforme previsto no artigo 95 do ECA. Entretanto, este trabalho teve como objetivo analisar apenas como a fiscalização das entidades executoras de medidas protetivas é realizada pela Vara da Infância e da Juventude, órgão do Poder Judiciário.

Dentro da VIJ, existem dois procedimentos distintos em relação às crianças e adolescentes que recebem medida protetiva. Quando a criança e o adolescente encontram-se apenas na condição de vítima, o Conselho Tutelar é oficiado para acompanhar a execução das medidas protetivas aplicadas e deve recorrer à autoridade judiciária quando houver dificuldade nessa execução.

Quando o adolescente estiver em conflito com a lei, ou seja, na posição de vitimizador, e tenha recebido medida socioeducativa cumulada com medida protetiva, a responsabilidade pelo acompanhamento da execução da medida protetiva fica a cargo da própria entidade executora da medida socioeducativa. Nesses casos, o Conselho Tutelar não é oficiado.

Assim, tendo em vista que as unidades que executam as medidas socioeducativas estão sempre em contato com a autoridade judiciária para informar, por 
meio de relatórios, sobre os adolescentes que acompanham, caberia a elas informar também a respeito das medidas protetivas e, caberia, ainda, à Vara da Infância e da Juventude questionar a respeito das medidas protetivas. Afinal, as medidas protetivas visam à promoção da proteção integral.

Partindo da hipótese de que a fiscalização da execução das medidas protetivas não estava consolidada na Vara da Infância e da Juventude do DF, evidenciou-se que existe uma diferenciação quanto à fiscalização das medidas protetivas, que se apresenta mais consolidada em casos de crianças e adolescentes na condição de vítimas, em detrimento dos vitimizadores. 


\section{4 - CAPÍTULO III}

\section{A FiscalizaÇÃO da EXECUÇÃO dAS MEDIDAS PROTETIVAS CUMULADAS COM MEDIDAS SOCIOEDUCATIVAS NA VARA DA INFÂNCIA E DA JUVENTUDE DO DISTRITO FEDERAL}

Os resultados obtidos com a pesquisa deste trabalho apontaram duas respostas dialéticas em relação à hipótese inicial da pesquisa. A primeira denota a não comprovação da hipótese, tendo em vista que a VIJ fiscaliza a execução da medida protetiva de abrigo. Porém, a VIJ não fiscaliza a execução das medidas protetivas aplicadas aos adolescentes em conflito com lei, que também receberam medida socioeducativa, o que mostra que a hipótese da pesquisa foi comprovada, parcialmente.

Em suma, pode-se dizer que a fiscalização da execução das medidas protetivas está consolidada na VIJ apenas para um tipo de medida protetiva destinada a um público específico: crianças e adolescentes abrigados, ou seja, na condição de vítimas.

Por esse motivo, este capítulo foi dividido em duas partes: a que trata das crianças e adolescentes considerados apenas vítimas, e a que trata dos adolescentes considerados apenas como vitimizadores.

\section{1 - Fiscalização da execução das medidas protetivas: atenção dada a criança e ao adolescente na condição de vítima.}

Evidenciou-se, por meio desse estudo, que existe um entendimento diferenciado sobre qual o papel da VIJ em relação às medidas de proteção, conforme demonstram as entrevistas realizadas com os servidores que lidam, de alguma forma, com as medidas protetivas no contexto da VIJ.

Para o técnico administrativo que trabalha no Cartório da VIJ, a competência da Vara da Infância e da Juventude em relação às medidas protetivas é suplementar, cabendo ao Conselho Tutelar e a instituição executora da medida socioeducativa o papel de acompanhar a situação da medida protetiva.

A linha de pensamento da analista judiciária que atua na assessoria jurídica da VIJ assemelha-se a do técnico do Cartório, visto que na opinião da analista em questão 
o conselho tutelar também tem competência para fiscalizar e como é ele o responsável por essas medidas de proteção, ele pode estar fiscalizando essas entidades. E, a partir do momento que ele não conseguir dar uma solução ou não for atendido, ele pode trazer o caso ao juízo. E aí o juízo vai exercer uma fiscalização já com um processo mais formalizado. Então essa medida de proteção tem isso, como ela é do conselho tutelar, a nossa competência fica bem restringida aos casos como de medidas socioeducativa ou então os casos que o conselho tutelar passe para nós (grifo meu).

Ou seja, para ambos os funcionários entrevistados, o Conselho Tutelar é o principal responsável pelas medidas protetivas. Entretanto, conforme já foi mencionado, o ECA estabelece que a responsabilidade de fiscalizar as entidades que executam programas protetivos é do Poder Judiciário, Ministério Público e Conselho Tutelar (art. 95 do ECA), e, em nenhum momento o Estatuto menciona que a responsabilidade para com as medidas protetivas é do conselho tutelar, isoladamente.

É interessante salientar que o técnico do Cartório menciona, em sua fala, a dificuldade dos conselhos tutelares terem seu poder em relação às crianças e adolescentes legitimado pelos programas protetivos que atendem a esse público. Um exemplo disso é o fato do conselho tutelar poder oficiar às entidades executoras de medidas protetivas quando há vinculação de crianças e adolescentes nos programas dessas entidades, entretanto,

(...) ele sofre muita dificuldade. Por exemplo, a medida protetiva do art. 101, inciso III, de matrícula é comum o conselho tutelar oficiar ao juiz da VIJ porque foi aplicada a medida, mas eles não conseguem resultado. Os próprios órgãos do GDF resistem um pouco. Aí nesses casos, eles oficiam ao juiz, e nós oficiamos a instituição, e aí, sim, eles cumprem. O conselho tutelar sofre muita dificuldade pra oficiar as medidas, tipo a do art. 101 inciso III.

Essa dificuldade do Conselho Tutelar em ter o seu papel reconhecido e respeitado pela rede de atendimento à criança e ao adolescente pode ser exemplificada de acordo com Luseni Aquino

o Conselho Tutelar, embora tenha centralidade inquestionável no sistema de garantia de direitos, não possui prestígio social e político no mesmo patamar de seus parceiros. Seus membros não conformam um corpo profissional homogêneo, e sua atuação na área da infância e da adolescência está marcada por um sentido voluntarista e de busca de gratificação individual. Além disso, os Conselhos Tutelares não contam com a exata compreensão de seu papel na rede pelos demais 
atores e, sendo autônomos, não encontram respaldo institucional em nenhuma estrutura hierarquicamente superior, mas são alvos fáceis de manipulação política e partidarismos locais. (AQUINO, 2004, p. 349).

Em contraponto à opinião dos entrevistados mencionados anteriormente, a supervisora da Seção de Medidas Socioeducativas - SEMSE entende que as medidas protetivas são fundamentais, pois garantem direitos essenciais ao pleno desenvolvimento infanto-juvenil, "não se pode imaginar uma infância e adolescência saudáveis sem garantir a inserção escolar, profissional e nas áreas de saúde, lazer, cultura, enfim, naquelas ditas inclusivas". E que, dado essa importância das medidas protetivas "haveria a necessidade de fiscalizar as demais medidas protetivas, previstas no art. 101 do ECA, exceto a prevista no inciso I (Entrega sobre Responsabilidade)" e, a partir dessa necessidade " a VIJ deveria implementar uma equipe responsável pelo acompanhamento dos programas protetivos, realizando visitas mensais a todos as equipes que executam o atendimento protetivo de crianças e adolescentes".

A supervisora da Seção de Estudos Técnicos - SET, que lida principalmente com as medidas protetivas, informou que a SET acompanha a execução das medidas protetivas em alguns casos, quando de maior gravidade. Para tanto, a Seção encaminha a criança e/ou adolescente para o cumprimento da medida protetiva e marca data para que os responsáveis comparecem à Seção com comprovante de que o filho foi atendido pelo programa protetivo. Esse trabalho seria o de acompanhar a execução da medida protetiva, que, conforme já foi explicado, fica a cargo do Conselho Tutelar.

Quanto à fiscalização da execução das medidas protetivas, por meio das entidades de atendimento, a supervisora da SET informou que a Seção não tem pessoal suficiente para poder fiscalizar, portanto, dá-se prioridade na execução dos processos, que envolve estudo de caso, o que demanda muito tempo. Por esse motivo, ela propõe outra maneira de fiscalizar, em que a fiscalização das entidades deve ser dividida com as outras instâncias preconizadas pelo ECA, uma vez que “(...) dentro da realidade que a gente vive, a gente tem que somar esforços, é isso que eu acho, e apesar da lei dizer uma coisa, entendo que cada um faz uma fatia do bolo, porque juntos damos um bolo inteiro".

Além dessas diferenças sobre o papel da VIJ quanto à fiscalização dos programas protetivos e sobre de que forma essa fiscalização deveria ser feita, chegou-se também à conclusão de que a fiscalização da execução das medidas protetivas está posta 
na Vara da Infância e da Juventude para apenas um público: as crianças e adolescentes na condição de vítima. E, ainda assim, com restrições.

De acordo com Sarita Amaro (2004), segundo estudo do IPEA, o principal fator que consolida o argumento da vitimização

(...)é seu caráter desencadeador da agressão física ou sexual contra crianças, tendo em conta que a cronificação da pobreza da família contribui para a precarização e deterioração de suas relações afetivas e parentais. Nesse sentido, pequenos espaços, pouca ou nenhuma privacidade, falta de alimentos e problemas econômicos acabam gerando situações estressantes que, direta ou indiretamente, acarretam danos ao desenvolvimento infantil (IPEA, 2004, p. 44).

Conforme apontam o técnico do Cartório entrevistado, a analista judiciária da Assessoria Jurídica, e as supervisoras da SEMSE e da SET, a fiscalização das medidas protetivas está posta apenas para crianças e adolescentes em situação de abrigamento. E, segundo o técnico do Cartório, essa fiscalização

(...) não é uma fiscalização de repressão, de coibir, é muito mais parceria, para fiscalizar observando o que está errado e orientar para que se transforme em coisa certa. A não ser que haja realmente abuso, ou enfim, aí sim a instituição pode ser notificada, ou processo de infração administrativa aonde vai se apurar o caso e pode até chegar ao fechamento da instituição. Mas não é comum ocorrer não.

Ou seja, apenas a Comissão de Fiscalização das Entidades é que realiza fiscalização de medida protetiva. A comissão é responsável por fiscalizar a execução da medida protetiva de abrigo. Segundo foi informado pela supervisora substituta da comissão, essa fiscalização acontece por meio de visitas aos abrigos, em que é vistoriada a estrutura física, os trabalhos desenvolvidos com os abrigados, estabelece-se comunicação com o corpo técnico (quando existe) e com o corpo administrativo da instituição fiscalizada. A comissão também orienta os abrigos em relação aos aspectos legais que estes devem cumprir.

Segundo expõe Aline Siqueira e Débora Dell’Aglio (2006), existem muitas dificuldades enfrentadas nos abrigos, decorrentes de uma visão pautada na perspectiva de ajudar crianças abandonadas, o que reflete, em muitos casos, em um frágil compromisso com as questões desenvolvimentais da infância e da adolescência. As autoras apontam, ainda, que 
(...) uma vez que a instituição de abrigo é necessária, é preciso que ela seja de pequeno porte, assegure a individualidade de seus integrantes e possua uma estrutura material e de funcionários adequadas. É necessário transformá-la num ambiente de desenvolvimento, capacitando-a e instrumentalizando- a (SIQUEIRA e DELL'AGLIO, 2006, p. 78).

A respeito da importância que os abrigos possuem no desenvolvimento de crianças e adolescentes, vale ressaltar a extrema importância de fiscalizar as entidades de abrigos, visto que o abrigamento é medida protetiva excepcional e a vivência que as crianças e adolescentes abrigados têm nos abrigos deve ser o mais semelhante possível ao que se denomina de convivência familiar. Ou seja, o abrigamento é uma medida protetiva bastante complexa, e, portanto, exige que a sua execução seja fiscalizada para que o direito de crianças e adolescentes seja efetivado, visto que essas instituições

(...) assumem o lugar central na vida das crianças e dos adolescentes abrigados, e em função disso, é necessário investir neste espaço de socialização, buscando transformar as concepções socialmente estabelecidas, de forma a desestigmatizá-las (SIQUEIRA e DELL'AGLIO, 2006, p. 78).

Para além das visitas aos abrigos, a Comissão realiza alguns estudos de caso com o intuito de subsidiar as decisões judiciais a respeito do retorno de abrigados às famílias, bem como em colocação dos mesmos em família substituta. Para este último caso, existe um trabalho articulado com a Seção de Adoção.

Entretanto, apesar das outras medidas protetivas (exceto a colocação em família substituta) não terem caráter de excepcionalidade, a execução delas é extremamente importante na garantia dos direitos de crianças e adolescentes, afinal, escola, saúde e assistência social são direitos sociais preconizados pela Constituição Federal. Todavia, não existe na VIJ nenhuma seção que fiscalize a execução destas medidas protetivas.

Essa diferenciação no tratamento das medidas protetivas, a depender do público ao qual elas são aplicadas, pode ser evidenciada, mais uma vez, por meio da entrevista realizada com um analista do Cartório Infracional, que quando questionado sobre a importância das medidas protetivas para as instituições que lidam com a execução, afirmou que

(...) o problema é operacional, não é nem de importância das medidas. Até porque a importância é reconhecida pelo juízo, tanto que você tem setor que trata só desses processos, mas quando a criança e o adolescente estão na condição de vítima. Quando ele está na condição de vitimizador, o tratamento é diferenciado. Eu, particularmente, acho isso muito errado. 
E, ainda para as crianças e adolescentes em situação de violação de direitos, a fiscalização é restrita, porque só se fiscaliza a execução da medida protetiva de abrigamento, sendo as demais, esquecidas.

\section{2 - Fiscalização da execução das medidas protetivas cumuladas com medida socioeducativa: atenção ao adolescente na condição de vitimizador.}

Este estudo chegou à conclusão que não existe fiscalização da execução das medidas protetivas quando estas são aplicadas aos adolescentes que receberam medida socioeducativa, ou seja, estão em conflito com a Lei. Esses adolescentes são vistos apenas com o olhar da punição, são considerados somente como vitimizadores.

Todavia, se esquece que esses adolescentes estão inseridos do mesmo modo em um quadro de vulnerabilidade social que os caracterizam, também, como vítimas. Essa afirmativa pode ser evidenciada por meio do perfil que foi traçado dos adolescentes em conflito com a Lei que receberam medida socioeducativa cumulada com medida protetiva, apontado no capítulo anterior.

$\mathrm{Na}$ VIJ/DF, a Seção que lida com as medidas socioeducativas, conforme esclarecido no capítulo anterior, é a SEMSE, que tem como missão institucional "acompanhar e fiscalizar a execução das medidas socioeducativas aplicadas aos adolescentes atores de atos infracionais" (Entrevista com analista judiciária da SEMSE/VIJ/DF).

Quanto às medidas socioeducativas, a SEMSE desempenha uma série de funções. A função principal da Seção é acompanhar e fiscalizar as instituições executoras das medidas socioeducativas de internação, semiliberdade, liberdade assistida. Este acompanhamento/fiscalização é realizado por meio de visitas às instituições e elaboração de relatórios técnicos, esclarecimento de dúvidas, enfim, por meio da comunicação com as instituições.

Além de ser responsável por acompanhar e fiscalizar a execução das medidas em questão, a SEMSE orientava todos os adolescentes que eram sentenciados com as medidas de LA e PSC, e, neste atendimento de orientação, era que os técnicos verificavam a necessidade de aplicação de alguma medida protetiva. Nesse caso, elaborava-se relatório técnico sugerindo ao Juízo a aplicação da medida de proteção adequada ao caso. 
No atendimento de orientação, era preenchido um instrumental com diversas informações sobre o adolescente (ato infracional, família, escolaridade, etc.), que subsidiava a elaboração do perfil do adolescente atendido pela Seção, gerava algumas pesquisas e projetos para o Setor.

Apesar de ainda não conter, oficialmente, na missão institucional a fiscalização da execução das medidas protetivas, é importante esclarecer que tal atribuição foi acrescentada recentemente à missão da Seção. Convém destacar que a iniciativa de acrescentar as medidas protetivas na missão da Seção partiu dos próprios servidores do setor:

"A medida protetiva se insere como marginal (risos) na nossa seção. Na realidade eu vejo assim, tanto que o nome da seção é Seção de Medidas Socioeducativas. Não tem nada sobre protetiva. Agora no decorrer do nosso dia-a-dia, a gente percebe a importância dessa medida. Tanto é que a medida protetiva foi contemplada na missão da SEMSE, enfim, pelo fato da gente perceber essa necessidade".

E, a maneira como a fiscalização da execução das medidas de proteção tem sido pensada pelos técnicos pode ser representada a partir da fala de uma das analistas entrevistadas:

"Já existem algumas idéias, que a gente, dentro das nossas possibilidades, vai tentar colocar em prática. A idéia é de acompanhar talvez não individualmente os adolescentes, cada família, mas via as instituições que estão recebendo estes adolescentes e suas respectivas famílias".

Embora esse acompanhamento das medidas protetivas não esteja colocado, ainda, como atividade bem estruturada na Seção, existe iniciativa por parte de alguns servidores em acompanhar a execução da medida protetiva:

“... infelizmente nós não temos acompanhamento das medidas protetivas. A gente ainda não realiza esse acompanhamento e, quando ele é realizado, ele é realizado individualmente, por alguns técnicos, então a gente não sabe o que acontece com o cumprimento das medidas protetivas, essa é a realidade. São poucos casos que a gente tem acesso, que se sabe se o menino realmente foi pra terapia, se a família também foi inserida".

E, já existe alguma iniciativa da Seção como um todo em estabelecer comunicação com as instituições executoras:

"Já está sendo feito um trabalho dentro da SEMSE, a [...] é responsável pela organização da rede, ela está sempre atualizando os 
dados, já trouxe responsáveis das instituições pra conversar. Então já tem a semente, a gente tem é que fortalecer esse trabalho".

Entretanto, embora a Seção tenha iniciado algum trabalho relacionado à fiscalização da execução das medidas protetivas e este ser consenso de todos, ainda existe um entendimento diferenciado entre os servidores da própria Seção a respeito da responsabilidade de realizar tal atribuição.

(...) VIJ deveria implementar uma equipe responsável pelo acompanhamento dos programas protetivos, realizando visitas mensais a todos as equipes que executam o atendimento protetivo de crianças e adolescentes. Dessa forma, além de manter o Juiz informado a respeito da rede de atendimento, conheceria os casos em acompanhamento e apresentaria sugestões visando o melhor funcionamento dos programas.

Conclui-se, portanto, que a Seção, apesar de não apresentar um trabalho consolidado em relação às medidas de proteção, entende a importância destas e tem se organizado na construção de um projeto para fiscalizar a execução de medidas protetivas aplicadas aos adolescentes em conflito com a Lei.

Durante o processo de estágio realizado pela pesquisadora na SEMSE, surgiu a necessidade de entender quais os trâmites que a VIJ realizava para esses casos. Para tal finalidade, foram analisados os processos de infração dos adolescentes - PIA's com vistas a identificar a existência de alguns documentos e as informações contidas neles, conforme demonstra a tabela 4 .

Tabela 4 - Documentos analisados nos Processos de Infração dos Adolescentes Pesquisados

\section{Documentos analisados nos PIA's pesquisados}

\begin{tabular}{c|l}
\hline Documentos analisados & \multicolumn{1}{|c}{ Informações a serem coletadas } \\
\hline Ofícios & $\begin{array}{l}1-\text { ofícios emitidos pelo Cartório da VIJ/DF informando } \\
\text { aos programas protetivos sobre a vinculação dos } \\
\text { adolescentes; } \\
2-\text { ofícios emitidos pelos programas protetivos } \\
\text { informando à VIJ sobre a vinculação ou não dos } \\
\text { adolescentes. } \\
3-\text { ofícios emitidos pela VIJ solicitando aos programas } \\
\text { que atendem adolescentes em conflito com a lei } \\
\text { informações sobre o cumprimento de medidas } \\
\text { protetivas; }\end{array}$ \\
\hline Relatórios & $\begin{array}{l}\text { relatórios encaminhados pelas instituições executoras } \\
\text { de medidas socioeducativas informando sobre a } \\
\text { execução das medidas protetivas. }\end{array}$ \\
\hline
\end{tabular}




\begin{tabular}{l|l}
\hline Sentenças & $\begin{array}{l}\text { - existência de sentença aplicando a medida protetiva ao } \\
\text { adolescente; } \\
\text { - existência de sentença revogando as medidas protetivas } \\
\text { aplicadas. }\end{array}$ \\
\hline
\end{tabular}

Dos 12 adolescentes que receberam a medida protetiva do inciso III, matrícula e freqüência obrigatória na escola, apenas em dois processos havia relatório da LA informando sobre a matrícula do jovem na rede de ensino. Entretanto, nenhum dos relatórios informava sobre a freqüência dos jovens. Em três casos, os adolescentes foram liberados das MSE's e não constava no PIA nenhuma informação sobre a matrícula e frequiência dos jovens. Em dois casos, as medidas socioeducativas foram revogadas, uma por conta de o adolescente ter cometido infração mais grave e ter recebido semiliberdade; e, no outro, o adolescente encontrava-se em local incerto e não sabido. Em ambos os casos, havia apenas ofício do Cartório informando à SUBIP sobre a matrícula dos mesmos. Somente em um caso consta declaração de que o adolescente foi matriculado e está freqüentando a escola, e trata-se de declaração emitida por escola do entorno do DF.

Constata-se, a partir das informações acima citadas, que a medida protetiva de matrícula resume-se a oficiar a instituição e nada mais. Dos doze adolescentes que a receberam, nove ${ }^{20}$ estavam em Liberdade Assistida, e desses, em apenas dois processos havia relatório que mencionava a matrícula dos adolescentes na rede de ensino, e que não falava sobre a freqüência dos mesmos à escola. Nos demais casos, a LA não se pronunciou a respeito e o Juízo não questionou sobre.

Sobre este ponto, Gallo e Williams informam que

O cumprimento da medida socioeducativa implica o acesso à educação formal, porém isso não acontece de fato. O Estatuto da Criança e do Adolescente prevê que os jovens em cumprimento de medidas socioeducativas devem freqüentar o ensino regular. Ademais o ECA reza que se tais jovens estiverem fora da escola o orientador da medida deverá encaminhá-los para o ensino formal. A despeito dos esforços para efetivar as matrículas, os educadores de medidas socioeducativas afirmam que, na maioria das vezes, as escolas justificavam a rejeição da matrícula dos adolescentes em conflito com a lei porque tais jovens, quando estavam na escola, causaram problemas, devendo, portanto, ser encaminhados para outras escolas. Estas, por sua vez, rejeitam esses alunos por seu histórico de conflitos

\footnotetext{
${ }^{20} \mathrm{O}$ três adolescentes restantes que receberam a MP do art. 101, inciso III, receberam as medidas socioeducativas de Prestação de Serviço à Comunidade, Prestação de Serviço à Comunidade cumulada com Visita ao CAJE, e Visita ao CAJE, respectivamente. É importante ressaltar que cabe somente à Liberdade Assistida acompanhar o adolescente em relação à escola, segundo art. X do ECA.
} 
e pelo estigma de estarem em conflito com a lei e assim o ciclo de exclusão se repete (GALLO\&WILLIAMS, 2008, p. 51).

A segunda medida protetiva mais aplicada diz respeito à inclusão do jovem em programa oficial ou comunitário de auxílio, orientação e tratamento a alcoólatras e toxicômanos (art. 101, inciso VI). Em cinco dos processos observou-se que o Adolescentro foi oficiado sobre a aplicação da MP ao adolescente. Contudo, não constam relatórios da instituição informando sobre o jovem e nem ofícios da VIJ solicitando informação. Também em cinco dos processos houve revogação da medida socioeducativa, entretanto não havia documento informando sobre a execução das medidas protetivas. Em apenas um caso não foi expedido ofício para o Adolescentro, vinculando o jovem àquela instituição.

A medida protetiva do art. 101, inciso V (tratamento médico, psicológico ou psiquiátrico) foi aplicada em 50\% dos casos estudados. Em todos os PIA's havia ofícios do Cartório informando ao COMPP - Centro de Acompanhamento Médico PsicoPedagógico $^{21}$ - sobre a vinculação dos adolescentes àquela instituição. Em três casos, o COMPP informou à VIJ que não atenderia os adolescentes por estes terem completado a maioridade penal. Destes, em dois dos casos, as medidas socioeducativas foram revogadas; uma porque o adolescente cometeu infração na Justiça Criminal Comum, deixando de ser foco de atuação da VIJ; e a outra porque o adolescente cumpriu a LA conforme deveria. No terceiro caso, tendo em vista que o COMPP não mais atenderia o jovem, o CENFOR foi oficiado para executar o acompanhamento e, até 06 de maio deste ano, não constam mais informações no processo. Vale destacar que o adolescente deste caso foi sentenciado em 2005.

Em dois casos, existe apenas ofício da VIJ comunicando à instituição executora sobre a aplicação da medida protetiva. Não consta nenhum documento da instituição informando sobre vinculação do jovem ao serviço ou ofício da VIJ cobrando relatório por parte da instituição. E, em dois casos o COMPP se pronunciou. No primeiro, informando que jovem não compareceu à consulta e, até maio do corrente ano nada

\footnotetext{
${ }^{21}$ No DF, as instituições que mais executam a medida protetiva do art. 101, inciso V são: o COMPP Centro de Acompanhamento Médico Psicopedagógico, que tem como propósito resgatar a saúde mental da criança e do adolescente de zero a 18 anos incompletos; e o Adolescentro (também executor do inciso VI, do art. 101), um programa que atende adolescentes com idades de 10 a 19 anos incompletos, em situação especial por uso de drogas, conflitos com a lei e convivência de violência sexual e, que há um ano foi reconhecido como Centro de Atenção Psicossocial - CAPS, conforme publicação no Diário Oficial do DF (Portaria $n^{\circ} 47$, de 26/09/2006). Além dessas Instituições públicas, a VIJ possui alguns convênios com universidades particulares,como o UniCeub, que possui o CENFOR - Centro de Formação em Psicologia, que presta acompanhamento psicoterápico em diversas modalidades aos adolescentes que são encaminhados.
} 
havia sido feito. No outro caso, o adolescente era possuidor de Transtorno de Déficit de Atenção e fez exames no COMPP, entretanto, não há ofício da VIJ cobrando resultado dos exames e nem outras informações a respeito do caso.

Quanto à medida protetiva do art. 101, inciso II (orientação, apoio e acompanhamento temporários), esta foi aplicada em dois casos. No primeiro, a VIJ oficiou à unidade de execução da LA, solicitando informações a respeito e a Unidade informou sobre a inserção do jovem em programa de proteção social. No segundo caso, a VIJ oficiou ao Conselho Tutelar para acompanhar as medidas de proteção aplicadas ao adolescente e oficiou à Unidade de LA para encaminhar os relatórios para o Conselho Tutelar. Nestes dois casos, os PIA's ainda estão em tramitação e, em até 06 de maio do corrente ano, não havia mais informações nos processos. É importante destacar que as sentenças dos adolescentes datam de 2006.

Por fim, conclui-se de todas essas observações que a VIJ tem cumprido o seu papel de oficiar as instituições executoras das medidas protetivas. Entretanto, na maioria dos casos, não se sabe se o adolescente foi ou não vinculado à medida protetiva, se não foi, o porquê, e, caso tenha sido vinculado, quais são os resultados obtidos na execução da medida protetiva.

As entidades responsáveis pela execução das medidas socioeducativas e, por conseguinte, pelo acompanhamento das medidas de proteção, raramente se pronunciaram a respeito das medidas protetivas. A respeito dessa dificuldade, pode-se ressaltar o grande dilema da integração da rede de atendimento à criança e ao adolescente. Aquino (2004) aponta que

A dificuldade para promover a integração da rede não reside, entretanto, apenas no problema da não-incorporação das competências estabelecidas para cada órgão. $\mathrm{O}$ tema da incompatibilidade entre as diferentes culturas organizacionais também é um fator interveniente, sobretudo quando se tem em vista que a rede de proteção integral congrega em um mesmo espaço órgãos tradicionais e historicamente consolidados e estruturas novíssimas, sem precedentes na organização pública brasileira. Tome-se, por exemplo, os casos do Juizado da Infância e da Juventude e do Conselho Tutelar, órgãos que devem atuar juntos na defesa dos direitos de crianças e adolescentes. Por mais que o Juizado tenha sofrido mudanças institucionais importantes desde o advento da doutrina da proteção integral, pertence à estrutura de um poder que tem raízes profundas no quadro institucional do país e cuja cultura profissional está firmemente consolidada. Além disso, o órgão goza de alto capital simbólico na sociedade e conserva importância definitiva na aplicação das medidas de proteção a crianças e adolescentes no atual sistema. Sendo assim, seus membros muitas vezes ainda tendem a assumir a primazia na responsabilidade pelo 
encaminhamento dos problemas com que se deparam crianças e adolescentes no usufruto de seus direitos, numa atitude francamente corporativista e auto-elogiosa da atuação do Judiciário, e às vezes desvalorizadora dos demais órgãos (...) (AQUINO, 2004, p. 349).

Ademais, observou-se, também, que a VIJ libera ou revoga as medidas socioeducativas sem ter dados a respeito das medidas protetivas, o que aponta certo descaso com as medidas de proteção.

Nos poucos casos em que o COMPP, por exemplo, informou que não poderia atender aos adolescentes por estes serem maiores de idade, somente em um processo a VIJ encaminhou o adolescente para outra instituição.

Para além dessa questão, podemos observar que a VIJ, mais precisamente, a SEMSE, fiscaliza a execução de todas as medidas socioeducativas, e, sobre este ponto, surge a reflexão de que a Justiça está mais preocupada em punir, do que em proteger as crianças e adolescentes. Conforme delineia Focault, "nenhum crime cometido pode escapar aos olhos da justiça, pois é a esperança de impunidade que fragiliza a aplicação da lei (...) mais severo, é preciso ser mais vigilante" (FOCAULT, p. 81).

Mário Volpi (2001, p. 57), traz a complementação de que esta perspectiva tão somente punitiva sobre o ato infracional vem sendo administrada com maior ou menor tolerância a depender das estruturas ideológicas predominantes em cada período histórico e que "mais que uma disfunção, inadequação comportamental ou anomalia, o delito é parte viva da sociedade $[\ldots .$.$] ".$

Dessa forma, pode-se dizer que a fiscalização da execução das medidas protetivas está voltada para crianças e adolescentes na condição de vítima porque a execução das medidas de proteção não é fiscalizada no caso de adolescentes em conflito com a Lei. Essa não fiscalização ficou ainda mais evidente com a análise dos processos $^{22}$, que mostrou que a VIJ raramente questionava o órgão executor da medida socioeducativa sobre a medida protetiva e, em muitas sentenças era revogada apenas a medida socioeducativa.

Para finalizar, é oportuno frisar que o problema da violência atinge de maneira mais preocupante o jovem, ou como autor da infração ou como vítima, sobretudo, pressionado duplamente pela falta de oportunidades no mercado de trabalho e pelos fascínios de uma sociedade monetizada e consumista. Para tanto, Segalin e Trzcinski (2006, p. 15) citam Teixeira (2004) que "afirma que o homicídio é a primeira causa

\footnotetext{
${ }^{22}$ Vide subtópico 4.1.2.
} 
mortis de adolescente no Brasil, registrado em terceiro lugar no ranking mundial. Acrescenta Saraiva (1999) que a delinqüência juvenil representa menos de $10 \%$ dos atos infracionais praticados no país em comparação às infrações praticadas por imputáveis".

Consideradas estas questões, percebe-se que os adolescentes pesquisados neste estudo são, sobretudo, vítimas, longe de representarem majoritariamente os vitimizadores. E que, portanto, existe um equívoco da Justiça em focar o aspecto punitivo da atenção dispensada aos adolescentes em conflito com a lei. 


\section{CONSIDERAÇÕES FINAIS}

Antes de iniciar as pontuações a respeito deste trabalho, gostaria de salientar que a experiência de estágio que tive na Vara da Infância e da Juventude do DF, mais especificamente na Seção de Medidas Socioeducativas, me permitiu estabelecer contato direto com os adolescentes em conflito com a lei e suas famílias. Esse contato foi o grande motivador deste trabalho, visto que, por meio dele pude perceber o quanto o público atendido diariamente pela SEMSE não é constituído apenas por vitimizadores, mas, principalmente, por adolescentes vítimas da sociedade que só os observa quando é atingida pelos atos infracionais por eles praticados.

Essa compreensão, de que os adolescentes envolvidos na prática de ato infracional estão inseridos em situações de vulnerabilidade social da mesma forma que crianças e adolescentes considerados apenas vítimas, foi extremamente importante para que este trabalho realizasse um estudo crítico dos resultados encontrados.

A partir da análise dos dados obtidos foi possível entender que a Vara da Infância e da Juventude vem conduzindo os direitos de crianças e adolescentes no Distrito Federal de uma maneira ambígua. Apesar de existirem diferentes seções psicossociais, com equipes bem preparadas e capacitadas e que atendem as crianças e adolescentes que têm seus direitos violados, a resposta que a VIJ dá a esse público se diferencia a depender do papel que essas crianças e adolescentes desempenham, ou seja, de vítimas ou vitimizadores.

Para as crianças e adolescentes considerados apenas vítimas dos diversos tipos de violência (seja física, sexual, negligência, etc.), a VIJ conta com o trabalho desenvolvido pela Seção de Estudos Técnicos, que acompanha a execução das medidas protetivas de alguns casos, dado a gravidade destes. Quanto à fiscalização da execução das medidas protetivas, realizada por meio da fiscalização das entidades, a VIJ fiscaliza apenas a medida protetiva de abrigo (art. 101, inciso VII do ECA).

Contudo, apesar da VIJ não fiscalizar a execução das demais medidas de proteção, ela oficia ao Conselho Tutelar da localidade em que residem a criança e o adolescente para acompanhar a execução das medidas protetivas aplicadas.

Já os adolescentes em conflito com a lei, ou seja, os considerados vitimizadores, são atendidos pela Seção de Medidas Socioeducativas que acompanha e fiscaliza apenas a execução as medidas socioeducativas, ficando as protetivas de lado. E, além de não haver a fiscalização das medidas protetivas, o conselho tutelar não é oficiado quando a 
medida protetiva é aplicada em conjunto com a medida socioeducativa. A explicação para esta situação é que as unidades responsáveis pela execução das medidas socioeducativas ficam incumbidas do acompanhamento da execução das medidas protetivas. Todavia, conforme esta pesquisa evidenciou, nos casos das medidas socioeducativas em meio aberto, esse acompanhamento das medidas protetivas não tem sido realizado conforme prevê o ECA.

Nesse sentido, parece que apesar da existência da Constituição Brasileira e do Estatuto da Criança e do Adolescente, a prática é sempre a mesma. Muda-se a roupagem, mas a ação permanece, porque para mudar é necessário deixar a postura de espectador e mergulhar fundo na participação e na compreensão dos processos particulares e sociais geradores da violência cotidiana. Conhecer a problemática das crianças e adolescentes em risco social e pessoal e dos adolescentes em conflito com a lei é compreender que o processo de violência é uma construção coletiva, no contexto tanto familiar, como social, político e econômico. O espaço afetivo no grupo familiar dá lugar para a violência, porque é aí que as expressões da questão social, produto da desigualdade social, encontram-se respaldadas, sobretudo naqueles grupos em processo de vulnerabilidade social acentuado.

Em contrapartida, apesar de ainda não estar consolidada a fiscalização da execução das medidas protetivas quando aplicadas cumuladamente com medidas socioeducativas, a SEMSE tem se mobilizado para iniciar essa fiscalização.

Portanto, existe fiscalização da execução da medida protetiva de abrigamento e já existem iniciativas por parte da SEMSE em estabelecer essa fiscalização no caso dos adolescentes considerados vitimizadores, porém, elas estão postas como ações interventivas setorizadas, ignorando a doutrina da proteção integral que o ECA propõe. A proposta deve ser a de enfrentar as situações sociais, familiares e afetivas de crianças e adolescentes com seus direitos ameaçados e/ou violados e de adolescentes em conflito com a lei, sem distinção da condição de vítima/vitimizadores em que eles se encontram, até porque os vitimizadores são, acima de tudo, vítimas.

Um aspecto fundamental para a fiscalização da execução das medidas protetivas, é que essa fiscalização não pode ser pensada sem se avaliar a maneira como a rede de proteção à criança e ao adolescente está posta. A ideologia de Redes Sociais como uma política de atendimento traz para o contexto de justiça infanto/juvenil uma forma diferente de olhar e de agir: uma responsabilidade coletiva da sociedade e de suas instituições, governamentais ou não, na forma de viabilizar a proteção integral. E a 
viabilização da Lei implica a construção de Redes Sociais, considerando que, no cerne da 'proteção integral', está posta a ideologia que permeia todo o ECA: responsabilidade, compromisso e viabilização de recursos financeiros e humanos.

Por fim, arrisco dizer que, a partir dessas contradições evidenciadas por este trabalho e pela produção teórica que foi utilizada, o desafio maior posto para a sociedade brasileira é de garantir a proteção integral a crianças e adolescentes em risco pessoal e social e a adolescentes em conflito com a lei, sem traçar a distinção entre vítimas e vitimizadores, para então, implementar o projeto de sociedade que o Estatuto da Criança e do Adolescente introduz no seu texto. Este é um dos aspectos importantes do ECA: implementar uma política de atendimento que garanta a proteção integral, que envolva, antes de tudo, a articulação de pessoas/profissionais em torno de um objetivo comum que viabilize a solidariedade coletiva permanente. 


\section{REFERÊNCIAS BIBLIOGRÁFICAS}

ABRAMO, Helena Wendel; FREITAS, Maria Virginia de; SPOSITO, Marilia Pontes (Orgs.). Juventude em debate. São Paulo: Cortez, 2000.

ABREU, Charles Jean Inicio de. Estudo crítico ao estudo da crianca e do adolescente: Comentários e análises. Porto alegre: Síntese, 1999. 187 p

ADORNO, Sérgio. Criança: A Lei e a Cidadania. In: RIZINNI, Irene (Org.). A Criança no Brasil Hoje: Desafio para o Terceiro Milênio. Rio de Janeiro: Editora Universitária Santa Úrsula, 1993. p. 100-112.

AQUINO, Luseni Maria Cordeiro de. A rede de proteção a crianças e adolescentes, a medida protetora de abrigo e o direito à convivência familiar e comunitária: a experiência em nove municípios brasileiros. In: O Direito à Convivência Familiar e Comunitária: os abrigos para crianças e adolescentes no Brasil. Ipea: Brasília, 2004. P. 325 a 365.

ASSIS, Simone Gonçalves de; CONSTANTINO, Patrícia. Perspectivas de prevenção da infração juvenil masculina. In: Minayo, Maria Cecília de Souza; Souza, Edinilsa Ramos de. Violência sob o olhar da saúde: a infrapolítica da contemporaneidade brasileira. Rio de Janeiro, FIOCRUZ, 2003. p.163-198.

BITTENCOURT, Juliana. A reintegração familiar e o princípio do melhor interesse da criança. Monografia, 2005. Disponível em: <http://www.direitonet.com.br/textos/x/12/81/1281/>. Acesso em: 31 out. 2007.

BRASIL. Câmara da Reforma do Estado. Plano Diretor da Reforma do Aparelho do Estado. Brasília, 1995.

BRANCHER, Leoberto Narciso. Capítulo 3: Organização e Gestão do Sistema de Garantia de Direitos da Infância e da Juventude. In: Pela Justiça na Educação. Brasília: MEC/Fundescola, 2000, p. 122-156.

BRITO, Leila Maria Torraca de. Liberdade Assistida no Horizonte da Doutrina de Proteção Integral. In: Revista de Psicologia: Teoria e Pesquisa. Rio de Janeiro, AbrJun 2007, vol. 23 n. 2, pp. 133-138.

CARVALHO, Inaiá Maria Moreira de. Direitos Legais e Direitos Efetivos: Crianças, adolescentes e cidadania no Brasil. In RBCS - Revista Brasileira de Ciências Sociais, 
2005. Disponível em: http://www.anpocs.org.br/portal/content/view/111/54/. Acesso em: 23 ago 2007.

CASTRO, Jorge Abrahão de; AQUINO, Luseni. Texto para Discussão $\mathbf{n}^{\mathbf{0}} \mathbf{1 3 3 5}$. Juventude e Políticas Sociais no Brasil. IPEA: Brasília, 2008. Disponível em: http://www.ipea.gov.br/default.jsp. Acesso em: 22 Mai 2008.

CEPAL. Panorama Social de América Latina 2000. Santiago de Chile : CEPAL, 2000b.

COMBESSIE, Jean-Claude. O Método em Sociologia: o que é, como faz. Tradução de Maria Stela Gonçalves. São Paulo: Editora Loyola, 2004.

COSTA, Antonio Carlos Gomes da; LIMA, Isabel Maria Sampaio Oliveira. Capítulo 8: Estatuto e LDB: Direito à Educação. In: Pela Justiça na Educação. Brasília: MEC/Fundescola, 2000, p. 290-310.

CRESWELL, John. Projeto de Pesquisa: Métodos qualitativo, quantitativo e misto. Porto Alegre: Artmed - Bookman, 2007.

Declaração Universal dos Direitos das Crianças. UNICEF, 1959. Disponível em: <http://www.dhnet.org.br/direitos/sip/onu/c_a/lex41.htm>. Acesso em: 31 Out 2007.

Estatuto da criança e do adolescente, 1990 (Lei $n^{\circ}$ 8069, de 13 de julho de 1990): convenção sobre os direitos da criança. Departamento da Criança e do Adolescente Secretaria de Estado dos Direitos Humanos, Fundo das Nações Unidas para a Infância. Brasília: Ministério da Justiça, 2002.

FALEIROS, Vicente de Paula. Políticas para a infância e adolescência e desenvolvimento. In: IPEA. Políticas Sociais Acompanhamento e Análise. 11, 2005, p. 171-177.

FIGUEIRÊDO, Carlos Maurício Cabral. Ética na gestão pública e exercício da cidadania: o papel dos tribunais de contas brasileiros como agências de accountability. O caso do Tribunal de Contas de Pernambuco. In: VII Congresso Internacional del CLAD sobre la Reforma del Estado y de la Administración Pública, Lisboa, Portugal, 811 Out. $2002 . \quad$ Disponível em: http://unpan1.un.org/intradoc/groups/public/documents/CLAD/clad0044116.pdf 
GALlO, Alex Eduardo; WILliAMS, Lúcia Cavalcanti de Albuquerque. A escola como fator de proteção à conduta infracional de adolescentes. In: Cadernos de Pesquisa, v. 38, nº 133. São Paulo, 2008, p.41-59.

GARCIA, Margarida Bosch. Um Sistema de Garantia de direitos - fundamentação. In CBRAL, Edson Araújo. Sistema e garantia de direitos: Um caminho para a proteção integral. Recife: Cendhec, 1999. 389 p (Coleção Cadernos Cendhec; 8).

HOFLING, ELOISA DE MATTOS. Estado e políticas (públicas) sociais. Cad. CEDES, Campinas, v. 21, n. 55, 2001. Disponível em: $<$ http://www.scielo.br/scielo.php?script=sci_arttext\&pid=S010132622001000300003\&1 ng=pt\&nrm=iso $>$. Acesso em: 12 Dez 2007.

Juventude, violência e vulnerabilidade social na América Latina: desafios para políticas públicas. Brasília: UNESCO, 2002. 192 p.

MEZZOMO, Marcelo Colombelli. Aspectos da aplicação das medidas protetivas e sócio-educativas do Estatuto da Criança e do Adolescente: Teoria e prática. Santa Maria/RS. Disponível em: <http://www.ufsm.br/direito/artigos/processo-penal/medidassocio-educativas.htm>. Acesso em: 18 abr. 2008.

MINAYO, Maria Cecília de Souza (Org.); DESLANDES, Suely Ferreira; NETO, Otávio Cruz; GOMES, Romeu. Pesquisa Social: teoria, método e criatividade. Petrópolis, RJ: Vozes, 1994.

NETO, Wanderlino Nogueira. O Estatuto da Criança e do Adolescente, princípios, diretrizes e linha de ação. In CBRAL, Edson Araújo. Sistema e garantia de direitos: Um caminho para a proteção integral. Recife: Cendhec, 1999. 389 p (Coleção Cadernos Cendhec; 8).

PEREIRA, Potyara A. Política de Assistência Social: avanços e retrocessos. In: Cadernos do CEAM nº 11. Brasília: CEAM/UnB, 2002.

POPPER, Karl. Introdução à Lógica Científica; “Alguns Componentes Estruturais de uma Teoria da Experiência”. In: A Lógica da Pesquisa Científica. 9a ed. São Paulo: Cultrix. 1993: 27-159.

RIZINNI, Irene (Org.). A Criança no Brasil Hoje: Desafio para o Terceiro Milênio. Rio de Janeiro: Editora Universitária Santa Úrsula, 1993. 
RIZZINI, Irma. O Elogio do Científico - A Construção do "Menor" na Prática Jurídica. In: RIZINNI, Irene (Org.). A Criança no Brasil Hoje: Desafio para o Terceiro Milênio. Rio de Janeiro: Editora Universitária Santa Úrsula, 1993. p. 81-99.

ROCHA, E. G.; PEREIRA, J. F. Descentralização participativa e a doutrina da proteção integral da criança e do adolescente. Revista da UFG, v. 5, n. 2, dez. 200.3 Disponível em: <http://www.proec.ufg.br/revista_ufg/infancia/P_descentraliza.html>. Acesso em: 31 out. 2007.

SANTOS, Romualdo Anselmo dos. Controle Social da Política de Saúde no Brasil. Brasília, 1999. 118 p. Dissertação (mestrado) - Universidade de Brasília, Departamento de Ciência Política.

SEGALIN, Andreia; TRZCINSKI Clarete. Ato infracional na adolescência: problematização do acesso ao sistema de justiça. Revista Virtual Textos \& Contextos. $\mathrm{N}^{\mathrm{o}}$ 6, ano V, dez. 2006. Disponível em: http://revistaseletronicas.pucrs.br/ojs/index.php/fass/article/viewFile/1038/817. Acesso em: 25 abr 2008.

SILVA, Enid Rocha Andrade da. O perfil da criança e do adolescente nos abrigos pesquisados. In: O Direito à Convivência Familiar e Comunitária: os abrigos para crianças e adolescentes no Brasil. Ipea: Brasília, 2004. P. 41 a 70.

SIQUEIRA, Aline Cardoso e DELL'AGLIO, Débora Dalbosco. O impacto da institucionalização na infância e na adolescência: uma revisão de literatura. Psicol. Soc., Jan./Abr. 2006, vol.18, nº.1, p.71-80.

SOUZA, Marcos Francisco de. Condições, determinações e particularidades do processo de trabalho do assistente social nos órgãos do Poder Judiciário sediados em Brasília. Brasília, 2004. 228 p. Dissertação (mestrado) - Universidade de Brasília, Departamento de Serviço Social.

VEROENSE, Josiane Rose Petry; LUZ, Valdemar P. da (coord.). Direito da Criança e do Adolescente: volume 5. Florianópolis: OAB/SC Editora, 2006.

VEROENSE, Josiane Rose Petry. Os Direitos da Criança e do Adolescente. São Paulo: LTr, 1999.

VEROEnSE, Josiane Rose Petry. Temas de Direito da Criança e do Adolescente. São Paulo: LTr, 1997. 
VOLPI, Mario (org). Sem liberdade, sem Direitos: a privação de liberdade na percepção do adolescente. São Paulo: Cortez, 2001.

VOLPI, Mário. O adolescente e o ato infracional. São Paulo: Cortez, 1997, p.23 - 27. 


\section{ANEXOS}

\subsection{Instrumento de Análise dos Processos de Infração de Adolescentes que receberam medida(s) protetiva(s)}

1. Instrumental $\mathrm{n}^{\mathrm{o}}$. :

2.Sexo: ( )feminino ( )masculino

3. Data de Nascimento: _ _ _ _

4. Data da Sentença: ___ _ _ _ _

5.Local de Moradia:

6.Local da Infração:

7.Data da Infração:

8. O Adolescente estuda? ( ) sim ( ) não

9.Escolaridade:

10. Em caso de não estudar, houve alguma manifestação judicial a cerca da inclusão do adolescente ao sistema de ensino público? Se sim, qual?

11. Ato Infracional praticado:

12. Medida Socieducativa aplicada:

13. Media(s) Protetiva(s) aplicada(s):

14. Consta no PIA ofício expedido pelo Cartório para a Instituição à qual o adolescente foi encaminhado? ( ) sim ( ) não

15. Se sim, qual a instituição e qual a data?

16. Existe algum ofício no PIA solicitando relatório quanto ao cumprimento da medida protetiva aplicada ao adolescente? ( ) sim ( ) não

17. Existe algum relatório enviado pela Instituição para qual o adolescente foi encaminhado? ( )sim ( )não

18. Se sim, quais as informações importantes constam nesse relatório? 
19. O Adolescente faz uso de drogas? ( ) sim

( ) não

20. Se sim, qual (is)? ( ) Maconha ( ) Cocaína ( ) Thinner ( ) Merla

( ) Craque ( ) Outra:

21. Em caso de usuário de drogas, o adolescente foi encaminhado para algum tratamento/acompanhamento? Se sim, para qual instituição?

22. Comentários relevantes sobre a análise do processo:

\subsection{Roteiro de entrevista destinado as Analistas Judiciárias e Técnica Judiciária da Seção de Medidas Socioeducativas da VIJ/DF}

Nome/Cargo/Formação Profissional.

1) Quais são as atribuições da SEMSE? E, como as medidas protetivas estão inseridas no trabalho desenvolvido pela Seção?

2) De que forma as medidas protetivas estão relacionadas com as socioeducativas?

3) No contexto da VIJ, como as medidas protetivas estão inseridas na rotina da instituição? Existe fiscalização da execução das medidas protetivas?

4) Na sua opinião, qual a importância que as medidas protetivas têm na garantia e efetivação dos direitos de crianças e adolescentes e, especialmente, dos adolescentes autores de infração penal?

5) Alguma sugestão sobre a atuação da VIJ/SEMSE em relação às medidas protetivas. 


\subsection{Roteiro de entrevista destinado aos Assessores Jurídicos da VIJ/DF}

1) Nome da Entrevistada/Formação Profissional/Cargo

2) Qual o trabalho desempenhado pela Assessoria Jurídica?

3) Dentro deste trabalho, como as medidas protetivas estão coladas?

4) Existe fiscalização da execução dessas medidas aplicada pela VIJ/DF? Se sim, como isso acontece?

5) Você acha que a fiscalização dessas medidas está colocada enquanto atividade bem estruturada na VIJ/DF, de forma a assegurar os direitos das crianças e adolescentes conforme propõe o Estatuto da Criança e do Adolescente?

6) Você acha que a VIJ/DF, enquanto instituição normativa e fiscalizadora consegue promover a proteção integral à criança e ao adolescente?

\subsection{Roteiro de entrevista destinado aos Técnicos Administrativos do Cartório da VIJ/DF}

\section{Nome da Entrevistada/Formação Profissional/Cargo}

1) Qual a rotina das medidas protetivas dentro da VIJ/DF?

2) Qual o papel que o Cartório desempenha em relação a essas medidas?

3) As medidas protetivas, quando aplicadas cumuladamente com as medidas socioeducativas, possuem uma rotina diferenciada em relação às demais?

4) Quando uma instituição é oficiada para executar determinada medida protetiva, existe algum trabalho desenvolvido pelo Cartório ou demais Seções da VIJ que verifica se a instituição executou a medida protetiva?

5) O conselho tutelar tem o poder de estar oficiando as instituições com relação às medidas protetivas?

6) Quando uma instituição não executa a medida protetiva, ela é penalizada? Algum setor da VIJ/Cartório faz esse tipo de controle/fiscalização?

7) Por exemplo, o adolescente recebe uma protetiva para tratamento psicológico ou pra tratamento de drogadição no Adolescentro, e se o Adolescentro não atende o adolescente, ele não vai sofrer nenhuma penalidade por isso? 
8) E você não acha que isso mostra que as medidas protetivas não têm uma importância significativa para as instituições?

9) Quais seriam as suas sugestões para a melhoria do trabalho desenvolvido pelo Cartório no que diz respeito às medidas protetivas?

\subsection{Roteiro de Entrevista destinado à Supervisora da Comissão de Fiscalização das Entidades - VIJ/DF}

\section{Nome da Entrevistada/Formação Profissional/Cargo}

1) Qual a Missão Institucional da Comissão de Fiscalização das Entidades?

2) De que forma as medidas protetivas estão inseridas no trabalho desenvolvido pela Comissão?

3) Como é realizada a fiscalização da execução da medida de abrigo?

4) E as demais instituições executoras de medidas protetivas, são fiscalizadas? Se sim, como? Se não, por quê?

5) Na sua opinião, qual a importância que as medidas protetivas têm na garantia e efetivação dos direitos de crianças e adolescentes?

6) Alguma sugestão sobre a atuação da VIJ/Comissão em relação às medidas protetivas. 